\title{
Chemistry of carbofunctionally substituted hydrazones
}

\author{
Abdel-Zaher A. Elassar, Hicham H. Dib, Nouria A. Al-Awadi, \\ and Mohammad H. Elnagdi \\ Chemistry Department, Faculty of science, Kuwait University, P. O. Box 5969-Safat-13060, \\ Kuwait \\ E-mail: aelassar@yahoo.com
}

\begin{abstract}
Synthetic approaches and chemical reactivity of title compounds since 1894 to date are reported. Emphasis is placed on pinpointing old literature reports that need reinspection in light of modern techniques and recent advances in utilizing the title compounds as precursors to polyfunctional heteroaromatics.
\end{abstract}

Keywords: Tautomerism, arylhydrazones as nucleophiles, carbon Mitsunobu reaction, aryl hydrazones as precursors to polyfunctional azoles and azines, gas phase pyrolysis

\section{Table of Contents}

1. Introduction

2. Synthetic Approaches to Carbofunctionally Substituted Hydrazones

2.1. Condensation of functional aldehydes and ketones with hydrazines

2.2. Coupling active methylenes with aromatic and heteroaromatic diazonium salts

3. Structure Investigation

4. Chemical Reactivity

4.1. Introduction

4.2. Reaction with electrophilic reagents

4.2.1. Reaction with carbon electrophiles

4.2.2. Reaction with nitrogen electrophiles

4.2.3. Reaction with halogen electrophiles

4.3. Reaction with nucleophilic reagents

4.3.1. Introduction

4.3.2. Reaction with carbon nucleophiles

4.3.3. Reactions with nitrogen nucleophiles

4.3.4. Reaction with oxygen nucleophiles 
5. Intramolecular Processes

6. Reduction

7. References

\section{Introduction}

Hydrazones in which $\mathrm{X}$ and $\mathrm{Y}$ are carbon functionality as $\mathrm{CO}_{2} \mathrm{R}, \mathrm{CN}$ are extremely important compounds in dye industry. ${ }^{1-3}$ Nitrogen lone pair resonance (cf. Scheme 1) renders hydrazone carbon atom electron rich and nucleophilicity of this carbon atom although have been noted in old literature ${ }^{4}$ has now been recognized and utilized extensively in synthesis. Despite their theoretical and practical importance to our knowledge, no trial to review reported chemical reactivities, structural studies and synthetic approaches to those molecules has ever been made. In the following article we review the chemistry of this class of compounds. Arylhydrazono azoles, azines and their condensed derivatives if having an $\alpha$-functional group on ring nitrogen (e.g. 3 and or 4) are not considered in this review as plenty of these derivatives have been extensively utilized as dyes and their chemistry is reviewed in specialized dye chemistry texts ${ }^{3}$. The chemistry of hydrazonyl halide $\mathrm{X}$ or $\mathrm{Y}=$ halogen and of hydrazononitriles $\mathrm{X}$ or $\mathrm{Y}=\mathrm{CN}$ have been surveyed recently and will not be included here.

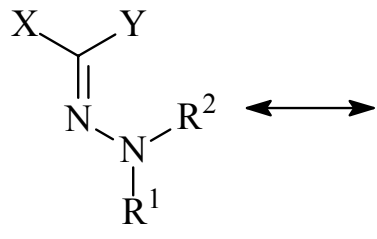

1

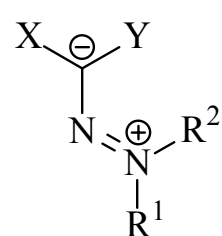

2<smiles>[X]C1=[V]C=C/C1=N/N</smiles>

3<smiles>[Y]C1=[Y]C([R])C([R])C(=NN[AlH2])C1[Y]</smiles>

4

\section{Scheme 1}

\section{Synthetic Approaches to Carbofunctionally Substituted Hydrazones}

\subsection{Condensation of functionalized aldehydes and ketones with hydrazines}

This is a most logical route provided the required $\alpha$-functional aldehyde and / or ketone is easily obtainable. As functionally substituted aldehydes are generally difficult to obtain and store this route however has only relatively limited application for the synthesis of monofunctionally substituted hydrazone ${ }^{5-11}$

Condensing glyoxal 5a and substituted glyoxal $\mathbf{5 b , c}$ with substituted hydrazines leads to formation of mono or bis hydrazones 6 or 7 depending on molar ratio and applied reaction 
conditions $^{5-11}$ It has been reported that $\mathbf{5 b}$ reacts with phenylhydrazine to yield initially $\mathbf{8}$ which then rearranges into the thermodynamically stable 6; $\mathrm{R}=\mathrm{CH}_{3}$ (cf. Scheme 2). The mechanism of this rearrangement however had to be classified although reversibility of initial condensation reaction might be visional and that 8 is the kinetic product.

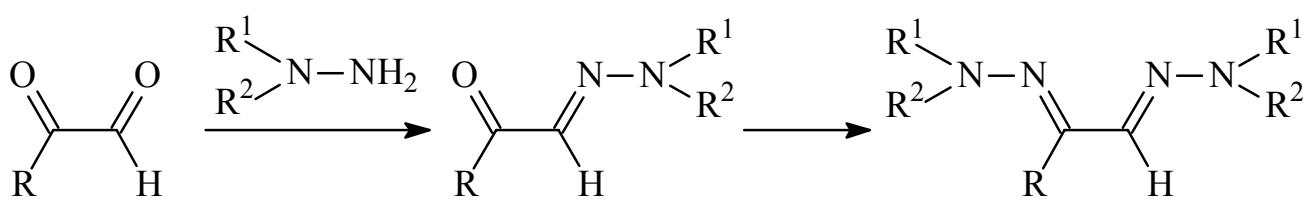

5a : $\mathrm{R}=\mathrm{H}$ 6

b : $\mathrm{R}=$ alkyl

c : $\mathrm{R}=$ aryl

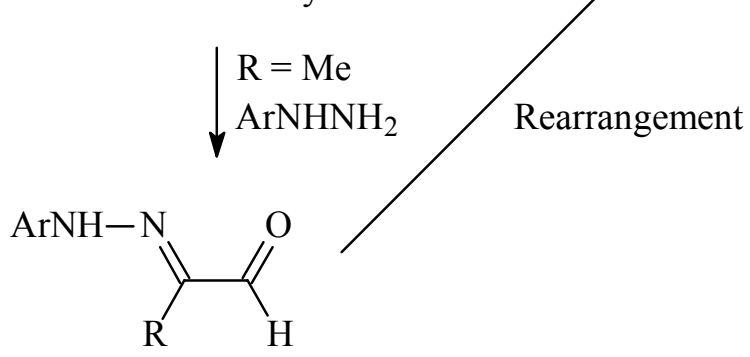

8

\section{Scheme 2}

\subsection{Coupling active methylenes with aromatic and heteroaromatic diazonium salts}

This is the most generally utilized route to $\mathbf{1}$. The coupling reaction is generally conducted at room temperature and in protic organic solvent in presence of a base. Sodium acetate is most commonly used but coupling in presence of sodium hydroxide or in pyridine solutions has been reported.

Acetylacetone 9a, benzoylacetone 9b, diphenylpentanedione 9c and other 1,3-diketones including cyclic ketones (e.g. 10a,b) have been coupled with aromatic diazonium salts in ethanolic sodium acetate to yield corresponding coupling products 11a-c ${ }^{12-20}$ and 12a,b ${ }^{21,22}$ (cf. Scheme 3). 
<smiles>[R]C(=O)CC([R])=O</smiles>
9a: $\mathrm{R}=\mathrm{R}^{1}=\mathrm{Me}$
b: $\mathrm{R}=\mathrm{Ph}, \mathrm{R}=\mathrm{Me}$
c: $\mathrm{R}=\mathrm{R}^{1}=\mathrm{CH}_{2} \mathrm{Ph}$
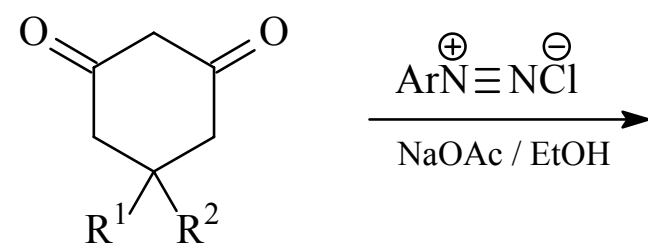

$$
\begin{aligned}
10 & \text { a: } R^{1}=R^{2}=H \\
\text { b: } R^{1}=R^{2} & =M e
\end{aligned}
$$<smiles>[R]C(=O)C(=NN[Al])C([R])=O</smiles>

\section{Scheme 3}

Similarly, oxobutanamide 13a and oxophenylbutanamide 13b couple readily to yield aryl hydrazones $\mathbf{1 4} \mathbf{a}, \mathbf{b}^{23-34}$ that have been extensively used as dyes and pigments (cf. Scheme 4).<smiles>[R]NC(=O)CC(C)=O</smiles>

13a : $\mathrm{R}=\mathrm{H}$

b : $\mathrm{R}=\mathrm{Ph}$<smiles>[R]NC(=O)/C(=N\N)C(C)=O</smiles>

$14 \stackrel{\mathrm{NH}}{\mathrm{Ar}}$

\section{Scheme 4}

Ethyl acetoacetate $\mathbf{1 5} \mathbf{a}^{35-50}$ ethyl cyanoacetate $\mathbf{1 5 b},{ }^{51-66}$ cyanoanilides $\mathbf{1 5 c},{ }^{67-69}$ benzoylacetonitrile $15 \mathbf{d}^{70}$ and cyanothioacetamide $\mathbf{1 5 f ^ { 7 1 , 7 2 }}$ couple readily with aromatic diazonium salt in presence of sodium acetate to yield corresponding arylhydrazones whose exact geometry has only been recently established $\mathbf{1 6}$ (cf. Scheme 5). 


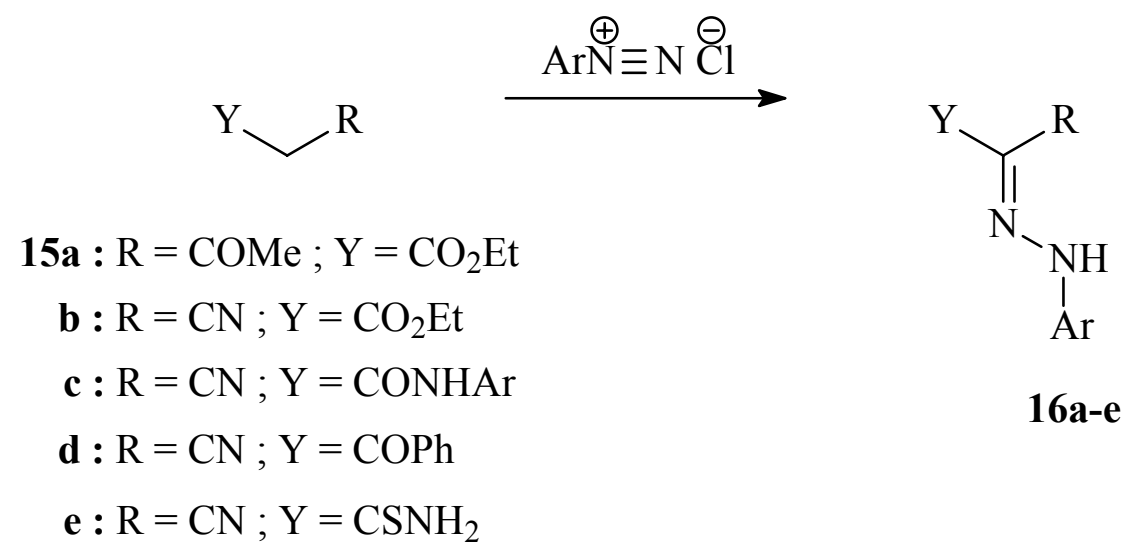

\section{Scheme 5}

The methylene functions in acetonitriles and benzylcyanide are not sufficiently reactive toward aromatic diazonium salts attempted coupling of cyanoacetic acid with aromatic diazonium salt affords only formazans $\mathbf{1 7 .}{ }^{73,74}$ However acetonitrile derivatives 18-23 readily couple with aromatic diazonium salts to yield the corresponding arylhydrazones $\mathbf{2 4 - 2 9}{ }^{\mathbf{7 5 - 8 6}}$ whose configuration have not yet been defined with certainty although structures have been assumed (Scheme 6). 


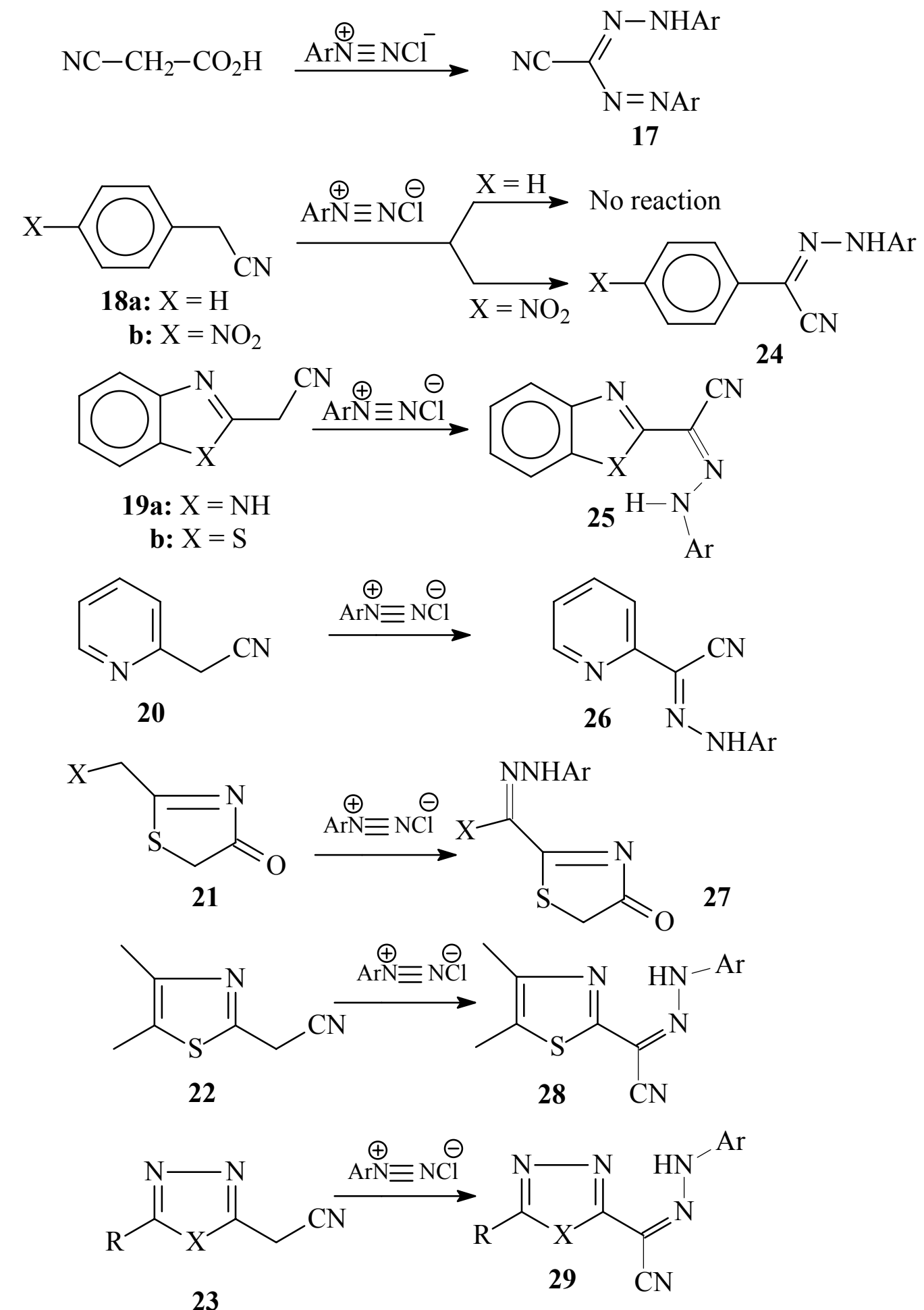

Scheme 6 
The methylene group in $\mathbf{3 0 ,} \mathbf{3 3}$ and $\mathbf{3 6}$ also couples with aromatic diazonium salts to yield intermediate functionally substituted arylhydrazones 31, 34 and 37 that readily cyclize into pyridazines $\mathbf{3 2}, \mathbf{3 5}$ and $\mathbf{3 8}$ ( cf. Scheme 7). ${ }^{87}$

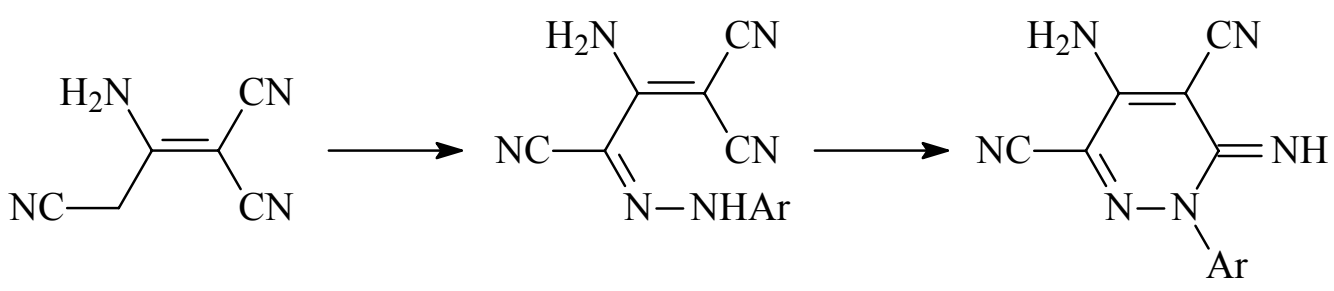<smiles>CCOC(=O)CCCCCCCCC(=O)OCC</smiles><smiles>[R]C(C)=C(C#N)C#N</smiles>

36

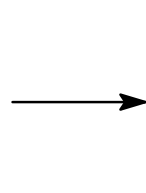<smiles>[R]C(/C=N/N[171I])=C(C#N)C#N</smiles>

37<smiles>[R]c1cnn([Ga])c(=N)c1C#N</smiles>

38

\section{Scheme 7}

Enamines 39 couple with aromatic diazonium salts to yield 2-arylhydrazonoaldehyde $41^{88-99}$ and arylhydrazonoketones in excellent yield. An intermediate derivative $\mathbf{4 0}$ is believed to be formed in all cases and could sometimes be isolated (Scheme 8).<smiles>[X]/C=C(/[R])N([R])[R]</smiles>

\section{Scheme 8}

$$
\begin{aligned}
& \mathrm{X}=\mathrm{H} ; \mathrm{COR}^{4}, \mathrm{CO}_{2} \mathrm{Et}, \mathrm{CHO}, \mathrm{CN} \\
& \mathrm{R}^{3}=\mathrm{H}, \mathrm{Me} ; \mathrm{R}^{1}, \mathrm{R}^{2}=\mathrm{H}, \text { alkyl }
\end{aligned}
$$


It has been recently observed that $\mathbf{4 2}$ couples with aromatic diazonium salt to yield arylglyoxal-2-arylhydrazones 45 . Formation of intermediate iminium ion $\mathbf{4 3}$ is believed to hydrolyze to $\mathbf{4 4}$ that undergo a Japp-Klingemann cleavage to $\mathbf{4 5}$ (cf. Scheme 9). ${ }^{100}$

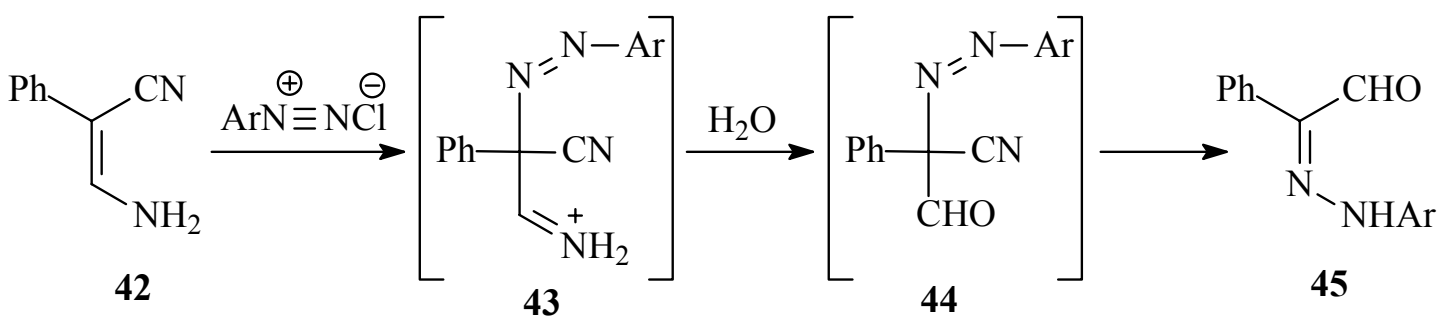

\section{Scheme 9}

Recent research at Kuwait and Cairo Universities showed that $N$-acetonylazoles 46a,b, 48, 50 and 52 couple readily with aromatic diazonium salts to yield arylhydrazonals $47.49,51$ and $\mathbf{5 3}^{101-107}$ whose stereochemistry have not been defined. Phenacylbenzotriazole $\mathbf{5 2}$ has been coupled with aromatic diazonium salts to yield $\mathbf{5 3}$ that was suggested to exist in a (Z)-form. This form is stabilized by H-bonding with benzotriazole N-2 (cf. Scheme 10). ${ }^{108}$ 
<smiles>[M]C(=O)Cn1[Y]nc2ccccc21</smiles>

46a : $\mathrm{X}=\mathrm{CH}$

b : $\mathrm{X}=\mathrm{N}$<smiles>CC(=O)Cn1[Y]cnc1</smiles>

48a : $\mathrm{X}=\mathrm{CH}$

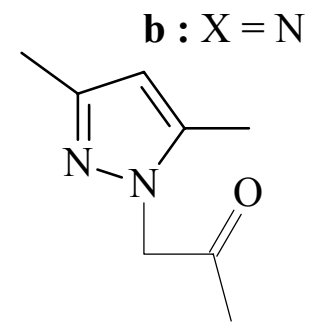

50<smiles>O=C(Cn1nnc2ccccc21)c1ccccc1</smiles>

52<smiles></smiles><smiles>C[Y]1cncn1C(=[NH2+])C(C)=O</smiles>

49 NNHAr

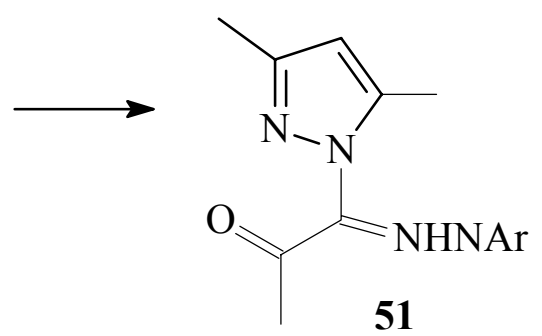

51

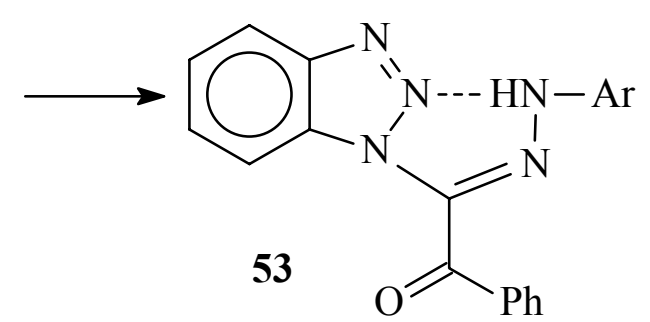

Scheme 10

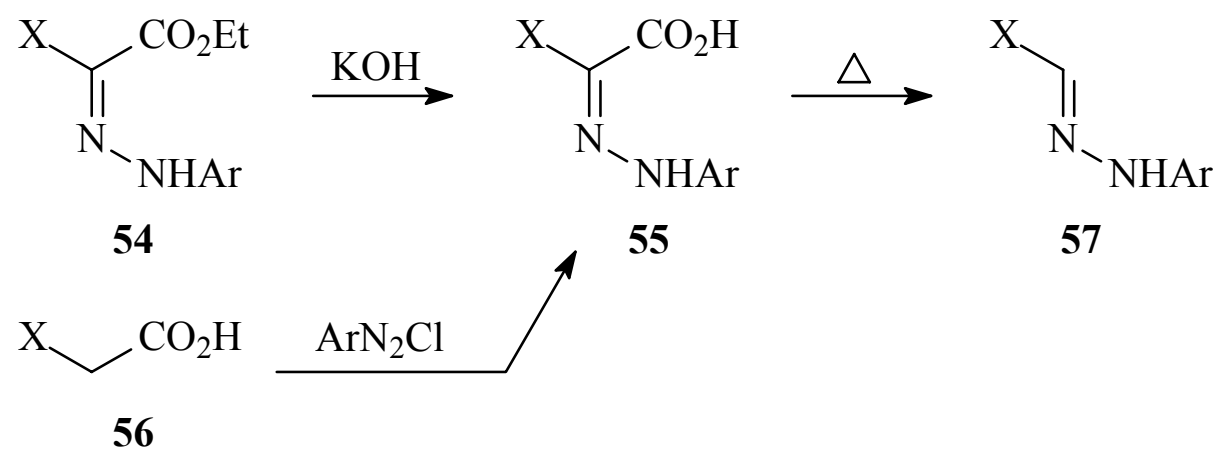

Scheme 11 
Functionally substituted arylhydrazones of type 1 where either $\mathrm{X}$ or $\mathrm{Y}=\mathrm{H}$ are generally prepared from the corresponding esters 54 via conversion into the acid $\mathbf{5 5}^{109-124}$ and subsequent decarboxylation to give 57. ${ }^{125-132}$ One step synthesis from the appropriate acids $\mathbf{5 6}$ has also been reported (c.f. Scheme 11). ${ }^{133,134}$

Interestingly coupling the enaminones $\mathbf{5 8}$ with aromatic diazonium fluoroborates have afforded 59. The structure of this unexpected product is supported by X-ray crystallography. It is believed to be formed via intermediacy as shown in Scheme 12. ${ }^{135,136}$

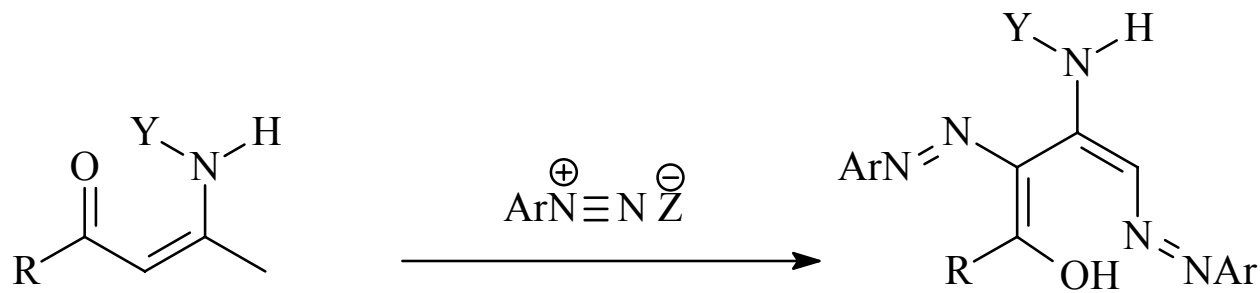

58
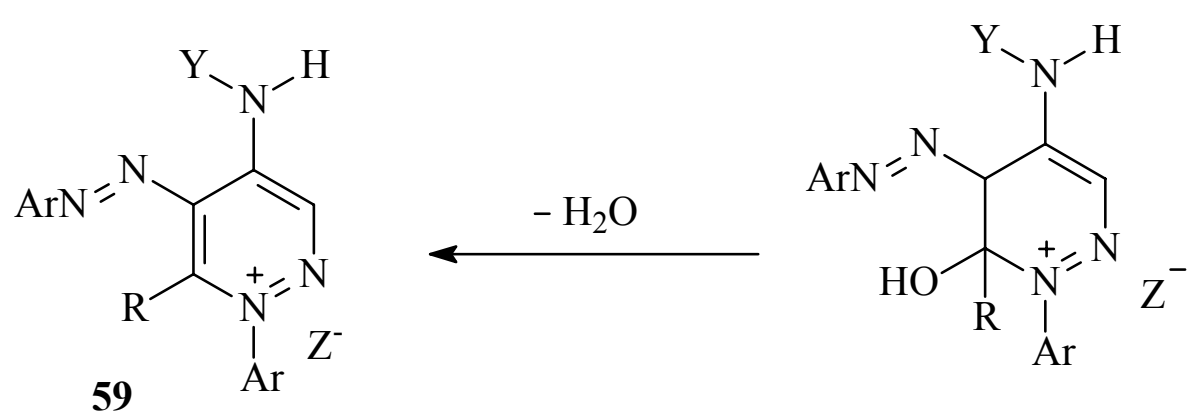

\section{Scheme 12}

\section{Structure Investigation}

$\alpha$-Oxohydrazones may exist in azo form $60 \mathrm{a}$, eneazo form $60 \mathrm{~b},(Z)$ - and $(E)$-hydrazone forms 61a and 61b. From time to time different methods utilizing roles variable for chemists by time presented at a supporting existence of these compounds in hydrazone form (cf. Scheme 13). 


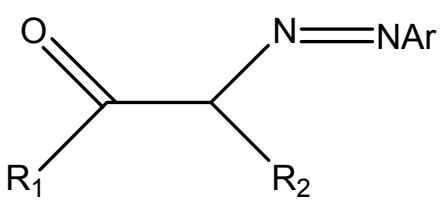

$60 a$

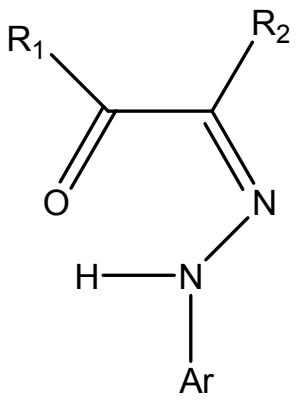

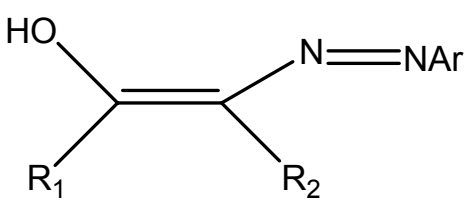

60b

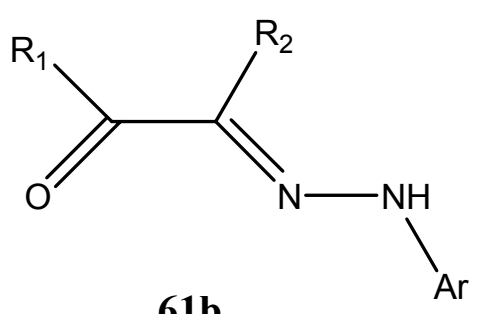

61a

\section{Scheme 13}

Thus, it was assumed by Bamberger et al. ${ }^{137}$ that (Z)-phenylglyoxal-2-nitrophenylhydrazones could be distinguished from the $(E)$ - isomer by its relatively lower melting point, as in $(E)$ recently H-bonding decrease tendency for association through intramolecular hydrogen bonding greater stability in certain solvents like benzene, deeper shade of colour and ease of crystallization. $^{137}$

Some authors believed that phenylhydrazones having a strong internal hydrogen bonding has a lower carbonyl band frequency in IR. ${ }^{138}$ This finding was utilized to differentiate between the $(Z)$ and $(E)$ forms of pyruvamide phenylhydrazone. ${ }^{139}$ The $(E)$ form showed the carbonyl band at higher frequency than that of the $(Z)$ form. On the other hand, IR studies ${ }^{140}$ of phenylglyoxalarylhydrazones indicate that the isomeric $(Z)$ and $(E)$ forms of these compounds can be easily distinguished by the position of the carbonyl as well as the NH stretching bands. Tanner $^{141}$ found that the carbonyl frequencies of both the $(Z)$ and $(E)$ forms of phenylglyoxal-2nitrophenylhydrazone were almost the same (1641 and $1640 \mathrm{~cm}^{-1}$, respectively) and that there was only a little difference in the NH stretching frequencies of these isomers (3128 and 3166, respectively).

The NMR of the hydrazone NH of $\alpha$-oxophenylhydrazones appears at $\delta 12-14 \mathrm{ppm}$. Studies of the isomeric forms in different solvents indicate that the equilibrium shifts in favor of $(E)$ form in solvents that favor hydrogen bonding formation.

The structure of phenyhydrazones of four $\alpha$-dicarbonyl compounds were determined from the IR and NMR spectra of the ${ }^{14} \mathrm{~N}$ and ${ }^{15} \mathrm{~N}$ isotopes. The compounds exist only in the phenyhydrazone tautomeric form and, except for the phenyhydrazones of phenylglyoxal in solution, primarily as the geometric isomer with the $\mathrm{NHC}_{6} \mathrm{H}_{5}$ group oriented away from the 
carbonyl. The effect of solvent on the composition of the geometric isomerism equilibria was discussed. ${ }^{142}$ El-Ashry et al. ${ }^{143}$ concluded that these compounds exist mainly in chelated hydrogen bonded form.

In the light of recent x-ray crystallography by Elnagdi et al. ${ }^{144-15-46}$ that arylhydrazono-3oxoalkene nitriles exists in $(E)$ form to make up for stereo electronic requirements previous conclusions about structure of arylhydrazo-ketones and ketoester should be rechecked (cf. structures 62-65).

It can thus be concluded that the observed low field $\mathrm{NH}$ signal in ${ }^{1} \mathrm{H}-\mathrm{NMR}$ is in fact due to extensive delocalization of nitrogen atom lone pair rendering hydrazone carbon atom electron rich. In support of this view ${ }^{1} \mathrm{H}-\mathrm{NMR}$ of phenylazomalononitrile showed $\mathrm{NH}$ signal at $\delta 13.0$ ppm. Here hydrogen bonding is not possible.<smiles>[R]C(=O)C1=NN([Al])[In]N(Nc2ccccc2)C1</smiles>

62<smiles>N#C/C(=N\N[Al])C(=O)c1cccs1</smiles>

63<smiles>N#C/C(=N\Nc1ccccc1)C(=O)c1ccccc1</smiles>

64<smiles>CC(=O)/C=N/Nc1ccccc1</smiles>

65

\section{Scheme 14}

\section{Chemical Reactivity}

\subsection{Introduction}

The most significant reactivity is the nucleophilicity of hydrazone carbon atom. This was noted since more than hundred years. Thus reactions like Mannich reaction, coupling reaction and halogenation have took place readily at such carbon. Recently Michael type addition was also described. Hydrazone nitrogen atom however remains the main site for attack by acylating and alkylating agents. It seemed that hard nucleophiles attack preferentially nitrogen atom, while soft ones attack preferentially at carbon atom.

The functional substituents retain their established reactivity pattern although generally become more electrophilic. Also multidentate reagents in several cases afford rings involving hydrazone moiety. In addition a variety of intramolecular cyclizations leading to cinnolines have been reported. In the following we will survey reported chemical reactivity pattern. 


\subsection{Reaction with electrophilic reagents}

\subsubsection{Reaction with carbon electrophiles}

The reaction of $\alpha$-ketohydrazones with Mannich reagents have been reported in the last century (c.f. formation of 67 from 66 is Scheme 15). Mustafa et al. ${ }^{147}$ have shown that 68 undergo Mannich reaction at hydrazone carbon atom to yield intermediates 69 that readily undergo JappKlingemann cleavage yielding $\mathbf{7 0}$ in good yields. This reaction has recently been adopted to aromatic aldehydes. ${ }^{14-151}$<smiles>[X]C=NN[Al]NC1CCCC1</smiles>

66

67<smiles>[R]C(=O)C(=NN[14CH3])C([R])=O</smiles><smiles>[R]C(=O)C(N=N[Al])(C(C)=O)C([R])N1CCC(C)CC1</smiles><smiles>[R]C(=O)/C(=N/N[Al])C([R])N1CCCCC1</smiles>

70

\section{Scheme 15}<smiles>[R]c1c(N=Nc2ccccc2)cnn1-c1ccccc1</smiles>

Scheme 16 
Glyoxaldiphenylhydrazone $\mathbf{7 1}$ also react with Mannich bases to yield either $\mathbf{7 2}$ or $\mathbf{7 3}$ depending on nature of utilized aldehyde (cf. Scheme 16). ${ }^{152-154}$

Aromatic aldehydes also react with $\mathbf{7 4}$ to yield $\mathbf{7 5}$. In absence of urea the reaction does not proceed. Naphthoquinone $\mathbf{7 6}$ reacts with $\mathbf{7 4}$ to yield either $\mathbf{7 7}$ or $\mathbf{7 8}$ depending on applied reaction conditions. Cinnamonitriles $\mathbf{7 9}$ also reacted with $\mathbf{7 4}$ to yield dihydropyridazines 80 (cf. Scheme 17). ${ }^{155}$<smiles>[R]C=C(C#N)CCc1cccc2c1C(=O)C=CC2=O</smiles>

80<smiles>[R]C(=O)/C(=N/N[14CH3])c1cc(O)c2ccccc2c1O</smiles><smiles></smiles>

\section{Scheme 17}

Treatment of ethyl 2-phenylhydrazono-3-oxobutanoate 16a phenylazoethyl-acetoacetate 16a with Vilsmeier reagent affords pyridazine carboxylic esters 81 (Scheme 18). ${ }^{156}$ 
<smiles>CCOC(=O)/C(=N\N[Al])C(C)=O</smiles>

$16 a$<smiles>CCOC(=O)c1nn([Al])cc(C=O)c1=O</smiles>

81

\section{Scheme 18}

In contrast to reported reactivity at carbon in this reaction, treatment of $\mathbf{1 6 b}, \mathbf{d}$ with alkylhalides affords $\mathrm{N}$-alkyl derivatives $\mathbf{8 2} \mathbf{a}, \mathbf{b}^{157-159}$ The reaction of $\mathbf{1 6 b}, \mathbf{d}$ with chloroacetone, chloroacetonitrile or ethyl chloroacetate affords aminopyrazoles 84, most likely, via intermediacy of non isolable acyclic 83. ${ }^{160}$<smiles>[R]C(=O)/C(C#N)=N/N[Te]</smiles>

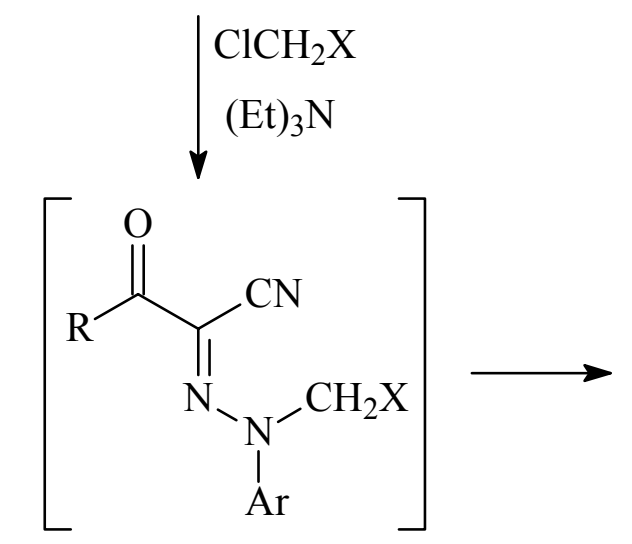

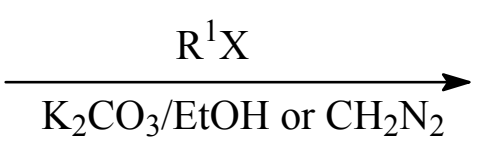

$$
\mathrm{K}_{2} \mathrm{CO}_{3} / \mathrm{EtOH} \text { or } \mathrm{CH}_{2} \mathrm{~N}_{2}
$$<smiles>[Te]</smiles>

83<smiles>[R]C(=O)/C(C#N)=N/N([R])[Al]</smiles>

82a,b<smiles>[R]C(=O)c1nn([Al])c([X])c1N</smiles>

84

\section{Scheme 19}

The reaction of 3-(2-phenylhydrazono)pentane-2,4-dione 11a with diazomethane afforded pyrazole 87 in addition to $\mathbf{8 5}$ and $\mathbf{8 6 .} .^{161,162}$ Although reaction sequence looks logical, this result should be checked again and reaction product should be characterized spectroscopically. 


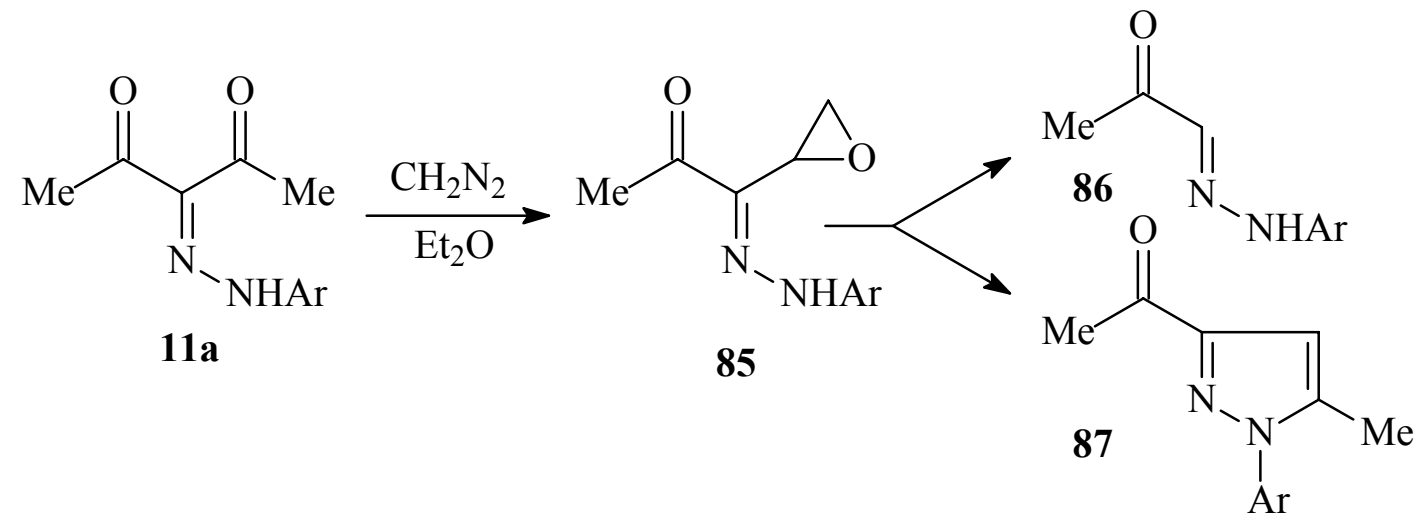

\section{Scheme 20}

Acetylation of $\mathbf{1 6 b}$ and $\mathbf{1 6 f}\left(\mathrm{R}=\mathrm{CO}_{2} \mathrm{Et}, \mathrm{Y}=\mathrm{COPh}\right)$ give 88a,b in good yield. ${ }^{163,164}$ Recently Elnagdi et $\mathrm{al}^{165}$ have reported both $\mathrm{N}$ and $\mathrm{C}$-acetylation and benzoylation of glyoxal diphenylhydrazones. Successful Vilsmeier formylation of $\mathbf{8 9}$ followed by cyclization and hydrolysis to yield pyrazole $\mathbf{9 0}$ has been also recently reported. ${ }^{166}$<smiles>[Y]C([R])=NN[Al]</smiles>

$16 b, f$

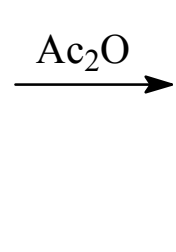

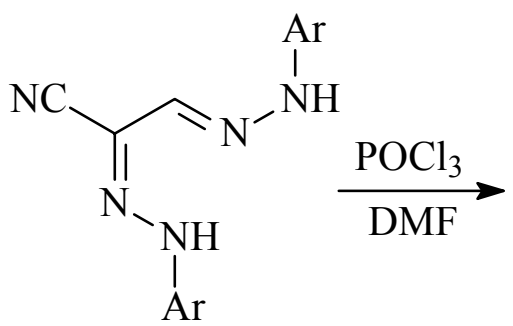

89<smiles>[R]C([X])=NN([Al])C(C)=O</smiles>

88a: $\mathrm{R}=\mathrm{CO}_{2} \mathrm{Et}, \mathrm{Y}=\mathrm{COPh}$

b: $\mathrm{R}=\mathrm{CO}_{2} \mathrm{Et}, \mathrm{Y}=\mathrm{CN}$<smiles>N=Nc1cn([Al])nc1C(N)=O</smiles>

90

Scheme 21 


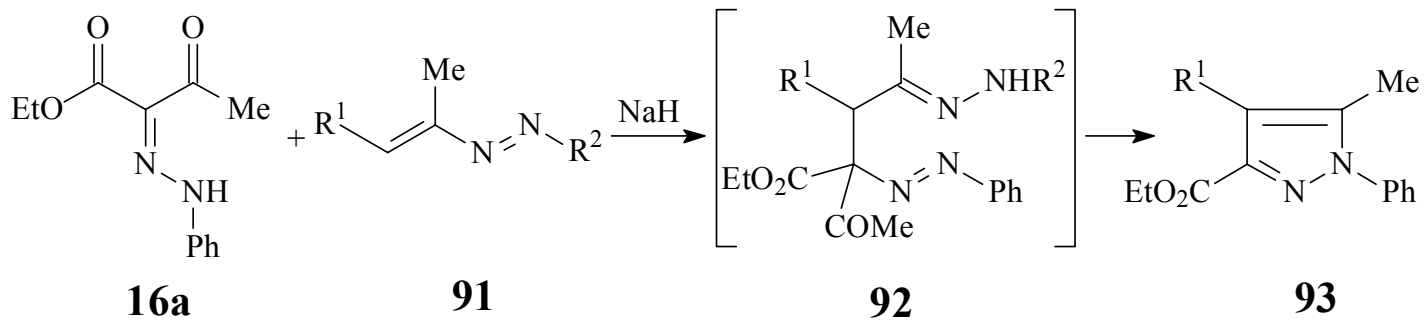

\section{Scheme 22}

The azadiene 91 reacts with $\mathbf{1 6 a}$ to yield the pyrazole 93 . Initial formation of adduct 92 is postulated. $^{167}$

The hydrazone nitrogen atom is the preferred site of attack by electrophilic $s p$ carbon atoms. Thus carbon disulphide reacts with 16 to yield 95 via intermediate 94 . similarly phenylisothiocyanate affords 97, most likely via intermediate 96. The reaction of 16 with chlorosulfonylisothiocyanate affords at $0-5{ }^{\circ} \mathrm{C}$ the chlorosulphonyl derivative 98 that is readily cyclized into 99 by aqueous $\mathrm{KOH}$ in presence of thiophenol. At $105-110{ }^{\circ} \mathrm{C}$ however enol form of 16 affords 101 via intermediacy of 100. ${ }^{168,169}$ It should be mentioned however that in absence of conversing spectral evidence supporting these structures reported conclusions seems highly unlikely. For example 97 can also cyclized to 1,2,4-triazine formation of N-N bonds or N-S bonds as well as highly strained non aromatic heterocycles seems in light of modern knowledge least likely. 


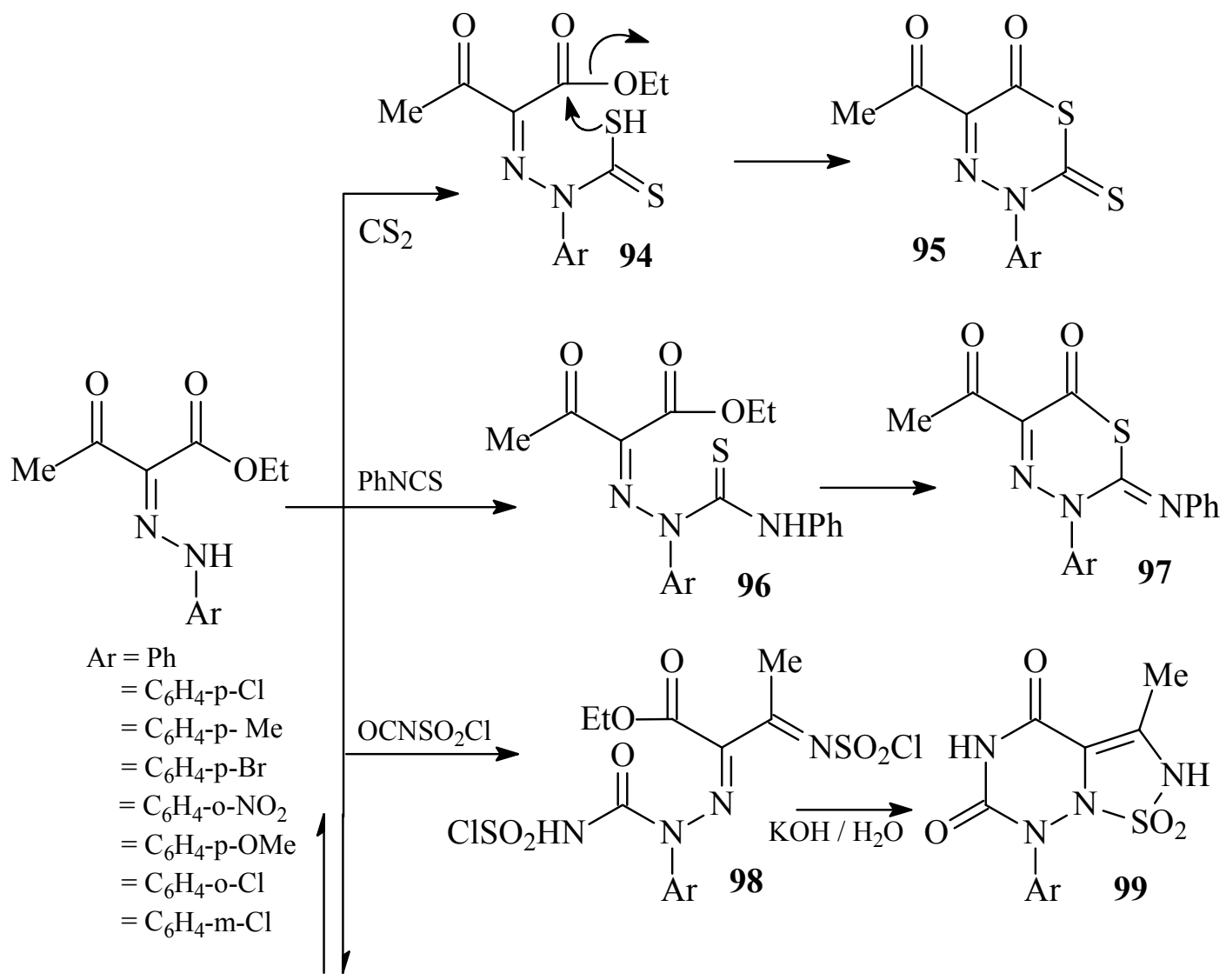<smiles>CCOC(=O)/C(N=N[Al])=C(/C)O</smiles>

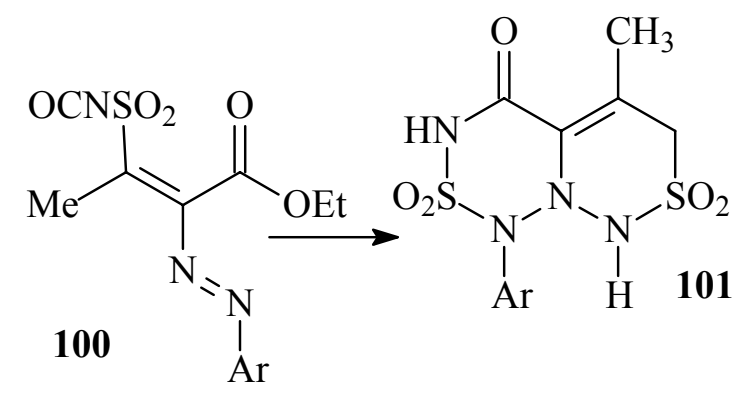

\section{Scheme 23}

\subsubsection{Reaction with nitrogen electrophiles}

Coupling occurs at hydrazone carbon atom and formed bisazo in case of hydrazones of type $\mathbf{1}$ coupled normally undergo a Japp-Klingemann cleavage of a functional group. Thus, 16a couple with aromatic diazonium salts to yield intermediate $\mathbf{1 0 2}$ that is directly converted into the isolable formazane $103 .^{170}$ 
<smiles>CCOC(=O)/C(=N\NC(C)=O)C(C)=O</smiles>

$16 a$<smiles>CCOC(=O)/C(N=N[Al])=N\N[14C]</smiles>

103<smiles>CCOC(=O)C(N=N[Al])C(C)=O</smiles><smiles>[13CH3][N+]#[Cl+3]</smiles><smiles>CCOC(=O)C1(N=N[Al])CCCCC1N=N[Al]</smiles>

102

\section{Scheme 24}

Formation of formazan $\mathbf{1 0 6}$ has been also observed upon coupling arylhydrazonoaldehyde 104a,b and/or 105 with aromatic diazonium salts (c.f. Scheme 25). ${ }^{171,172}$

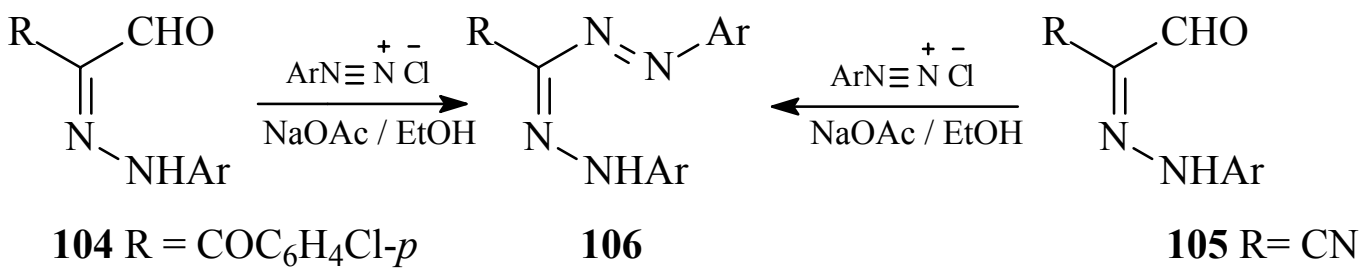

\section{Scheme 25}

Ethyl 2-phenylhydrazono-3-oxobutanoate $\mathbf{1 6 a}$ is readily nitrated at phenyl moiety on treatment with nitric acid to give $107 .^{24}$ 
<smiles>CCOC(=O)/C(=N\Nc1ccc([N+](=O)[O-])cc1)C(=O)NN=C(C(C)=O)C(C)=O</smiles>

\section{Scheme 26}

\subsubsection{Reactions with halogen electrophiles}

Halogenation occurs either at hydrazone carbon or at aryl or alkyl moieties depending on the nature of substituents on hydrazone moiety. Normally in acetic acid and in presence of sodium acetate halogenation occurs at hydrazone carbon and is followed by Japp-Klingemann cleavage of one of the functional groups attached to hydrazone carbon. If the hydrazone aryl moiety carry a strong electron attracting substituent (e.g. nitro function) initial halogenation occur at alkyl moieties in the molecule when they do exist. For example chlorination of $\mathbf{1 6 a}\left(\mathrm{Ar}=\mathrm{C}_{6} \mathrm{H}_{4} \mathrm{NO}_{2}\right)$ with chlorine gas gives the hydrazonyl halides 108. ${ }^{173-175}$ Bromine in acetic acid affords mono bromination products 109. If bromination is conducted in acetic acid in the presence of sodium acetate bromination at hydrazone carbon followed by Japp-Klingmann cleavage yielding 110 occurs. We believe that under such basic conditions the reacting species is a molecule of $\mathbf{1 6}$ that is capable of delocalizing negative charge on hydrazone carbon making it thus sufficiently nucleophilic. ${ }^{176-180}$ 
<smiles>CCOC(=O)/C(Cl)=N/Nc1cccc([N+](=O)[O-])c1</smiles><smiles>CCOC(=O)/C(Br)=N\Nc1ccc([N+](=O)[O-])cc1</smiles>

\section{Scheme 27}

It has been reported that if the arylhydrazone moiety is not substituted it can also participate in these reactions. For example chlorination of 16a with iodine chloride gives product of attack at both hydrazone carbon and phenyl moiety yielding 111. ${ }^{181}$ Bromination of 16a gives 112 . Utility of excess of bromine is believed to yield 113. ${ }^{182}$ Again spectroscopic evidence or X-ray crystallography is needed to support or revise these structures.<smiles>CCOC(=O)C(=NNc1ccccc1)C(C)=O</smiles>

112<smiles>CCOC(=O)/C(Cl)=N/Nc1ccc(I)cc1</smiles>

111<smiles>CCOC(=O)C(Br)N(Br)N(Br)c1ccc(Br)cc1Br</smiles>

\section{Scheme 28}


Deviations from the general pattern have been reported. It seems that as a result of the fact that good part of these investigations has been made before development of appropriate spectroscopic methods for structural elucidation led in several cases in concluding structures with no solid evidence. For example chlorination of $16\left(\mathrm{Ar}=\mathrm{C}_{6} \mathrm{H}_{4} \mathrm{NO}_{2}-\mathrm{p}\right)$ has been claimed to yield 114. ${ }^{183}$ In other report chlorination in acetic acid in presence of sodium acetate gave $\mathbf{1 1 5}$. We believe that concluded structure need to be reinvestigated. ${ }^{173}$<smiles>CCOC(=O)/C(=N/N)C(C)=O</smiles>

$16\left(\mathrm{Ar}=\mathrm{C}_{6} \mathrm{H}_{4} \mathrm{NO}_{2}-\mathrm{p}\right)$
$\mathrm{NaOAc}$

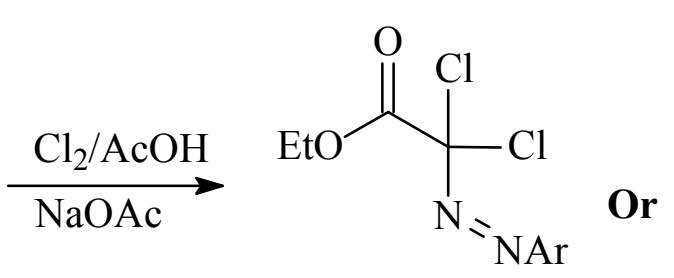

114<smiles>CCOC(=O)/C(Cl)=N/NCl</smiles>

115

\section{Scheme 29}

\subsection{Reaction with nucleophilic reagents}

\subsubsection{Introduction}

Plenty of condensations occur at carbonyl group in $\mathbf{1}$ and reactions of this type when both $\mathrm{X}$ and $\mathrm{Y}$ are carbofuncionallties lead to formation of arylazoheterocycles that are extensively utilized in dye industry. Condensation with bidentate reagents with electrophilic and nucleophilic moieties normally leads to pyridazine formation.

\subsubsection{Reaction with carbon nucleophiles}

Carbofuncion in ethyl 2-phenylhydrazono-3-oxobutanoate 16a condenses readily with ethyl cyanoacetoacetate to yield pyridazinones. This reaction type has been extensively utilized for synthesis of various functionally substituted pyridazines. ${ }^{184-191}$ Thus 16a,f,g afforded 116a-e while 16h,i gave the dicyanopyridazineones. Condensation of 16a with diethyl malonate also afforded diethyl pyridazine dicarboxylates. The reaction has been also conducted under microwave irradiation and afforded highly pure pyridazinone in much shorter time. ${ }^{184-191}$ 
<smiles>[R]C(=O)/C([Y])=N\N[Al]</smiles>

16a: $\mathrm{R}=\mathrm{H}, \mathrm{Y}=\mathrm{CO}_{2} \mathrm{Et}$

b: $\mathrm{R}=\mathrm{Me}, \mathrm{Y}=\mathrm{CO}_{2} \mathrm{Et}$

c: $\mathrm{R}=\mathrm{H}, \mathrm{Y}=\mathrm{CN}$

$\mathrm{d}: \mathrm{R}=\mathrm{Me}, \mathrm{Y}=\mathrm{CN}$

e: $\mathrm{R}=\mathrm{Ph}, \mathrm{Y}=\mathrm{CN}$<smiles>[R]c1nn([Al])c(=O)c(C#N)c1[Y]</smiles>

116 a-e

\section{Scheme 30}

Benzoylacetonitrile, cyclohexanone, cyanoacetamide and malononitrile were also condensed with arylazo derivatives to yield pyridazinones. ${ }^{192}$ The benzotriazolyl derivative 117 and the hydrazonopyruvate also condense with ethyl cyanoacetate to yield $\mathbf{1 1 8}$ and 119, respectively. ${ }^{186}$<smiles>[R]CC(=O)/C([R])=N/N[Al+2]</smiles><smiles></smiles>
b: $\mathrm{R}=\mathrm{H}, \mathrm{Me}$<smiles>[R]Cc1c([R])nn([Al])c(=O)c1C#N</smiles>

118<smiles>CCOC(=O)c1nn([Al])c(=O)c(C(=O)OCC)c1C</smiles>

119

\section{Scheme 31}

Condensation of 16 with 2-aminoprop-1-ene-1,1,3-tricarbonitrile 30 gives 122 via 120 and 121. ${ }^{193,194}$ Although this work has been published recently, the luck of convincing spectral evidence to support these conclusions seems quite strange as several alternate structures looks also possible. 
<smiles>CCOC(=O)/C(=N/N[14C])C(C)=O</smiles>

$16 a$<smiles>N#CCC(N)=C(C#N)C#N</smiles>

30
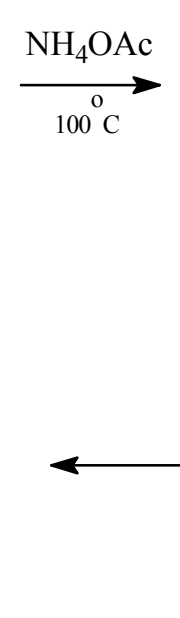<smiles>CCOC(=O)C(=N/N[Ga])/C(C#N)=C(/C#N)C(N)=C(C#N)C#N</smiles>

122<smiles>CC1=C2C(=O)NC(=O)C(C#N)=C2NC(=O)C1=N</smiles><smiles>CC1=C(C#N)C(=C(C#N)C#N)NC(=O)C1=NN</smiles>

\section{Scheme 32}

The arylhydrazonals $\mathbf{4 1}$ also reacted with ethyl cyanoacetate yielding pyridazinones 123. Wittigs reagents condense also with $\mathbf{4 1}$ to yield the corresponding pyridazinones $\mathbf{1 2 4}$ in good to excellent yields. ${ }^{195,196}$

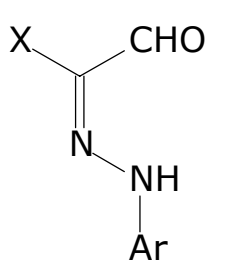

41 $\mathrm{X}=\mathrm{COR}$

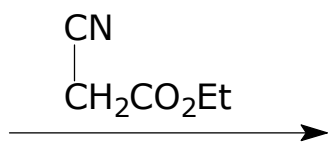

$\mathrm{Ph}_{3} \mathrm{P}=\mathrm{CHCO}_{2} \mathrm{Et}$

Toluene, heat $10 \mathrm{~h}$<smiles>[X]c1cc(C#N)c(=O)n([Ga])n1</smiles>

123

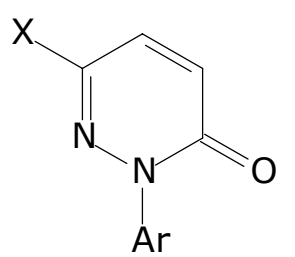

124

\section{Scheme 33}

A carbon Mitsunobu reaction of 41; $\mathrm{X}=\mathrm{CHAr}$ (or better a Baylis-Hillman like reaction) has been reported. Thus reacting 41; $\mathrm{X}=\mathrm{COAr}$ with dimethyl acetylene dicarboxylate and triphenylphosphine in methylene chloride gives the pyridazinedicarboxylates $\mathbf{1 2 5}$. It is believed that this reaction proceeds via sequence shown in Scheme 35. ${ }^{197,198}$ 


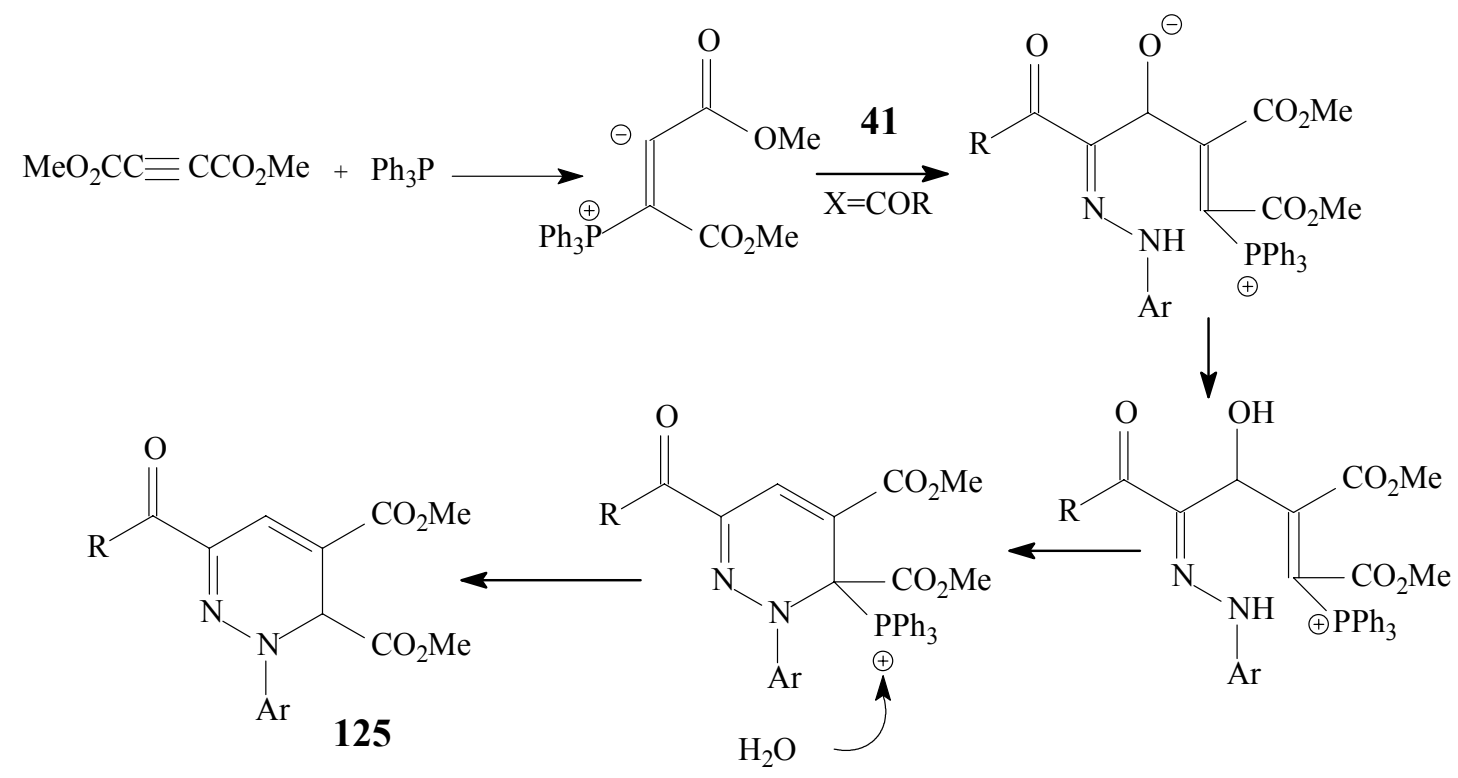

\section{Scheme 34}

The reaction of $\mathbf{1 6 a}$ with $\mathbf{1 2 6}$ gives $\mathbf{1 2 7} .^{199}$<smiles>CCOC(=O)/C(=N\c1ccccc1)C(C)=O</smiles>

$16 a$<smiles>[Pb]c1ccccc1</smiles>

126<smiles>CCOC(=CC(=Nc1ccccc1)N/N=C/c1ccccc1)C(C)=O</smiles>

$\downarrow$<smiles>CCC1=NN(c2ccccc2)C(Nc2ccccc2)C=C1</smiles>

127

\section{Scheme 35}


Phenols condense with 16 to yield chromene derivatives. For example condensation of $\mathbf{1 6 a}$ with resorcinol affords $\mathbf{1 2 8}$, salicylaldehyde gives $\mathbf{1 2 9} .^{35,37}$<smiles></smiles>

16a<smiles>Oc1cccc(O)c1</smiles>

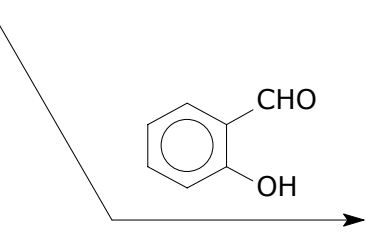<smiles>Cc1c(N=N)c(=O)oc2cc(O)ccc12</smiles>

128 or<smiles>Cc1c(N=[W])c(=O)oc2cc(O)ccc12</smiles><smiles>Cc1c(N=[W])c(=O)oc2c(C=O)cccc12</smiles>

129

\section{Scheme 36}

Cyanothioacetamide condensed with $\mathbf{1 6 a}, \mathbf{b}$ to yield 130 and 131, respectively. ${ }^{16}$<smiles>[R]C(=O)C(=NNC(=O)[O-])C([R])=O</smiles>

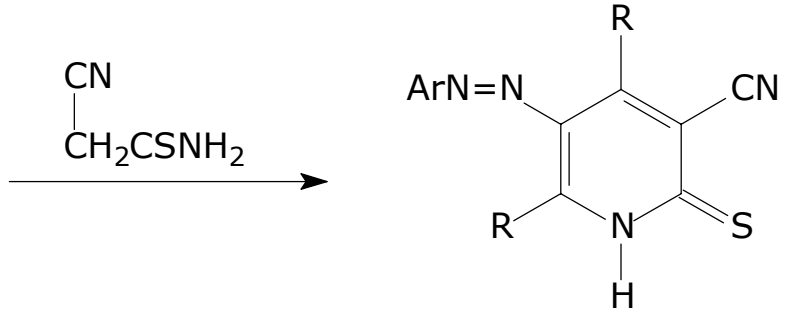

130<smiles>CCOC(=O)/C(=N/NC(=O)[O-])C(C)=O</smiles><smiles>N#CCc1ccccc1</smiles><smiles>[R]C1=C(C#N)C(=S)N([TlH])C(=O)C1=NN</smiles>

131

\section{Scheme 37}

Benzaldehyde condenses with 16a to yield pyridazinones 133. Intermediate 132 could be isolated. Compound 133 can also exist in enol form or may also readily autooxidize into 
aromatic pyridazinones. It seems that of value to reconfirm the suggested structure, condensation of benzothiazolylacetonitrile with $\mathbf{1 6}$ gives $\mathbf{1 3 4} .^{186,200,201}$<smiles>CCOC(=O)/C(=N/NBr)C(C)=O</smiles><smiles>CCCC(C)C(C)C</smiles><smiles>CCOC(=O)/C(=N/NBr)C(=O)/C=C/c1ccccc1</smiles><smiles>N#CCc1nc2ccccc2s1</smiles><smiles>CCOC(=O)c1nn(-c2ccccc2)c(=N)c(-c2nc3ccccc3s2)c1C</smiles><smiles>CCOC(=O)C1=NN(Br)C(c2ccccc2)CC1=O</smiles>

\section{Scheme 38}

The reaction of Grignard reagent 135 with 16a,d gives 136 and 138 which were readily dehydrated by reflux in acetic acid to yield 137 and 139 , respectively. ${ }^{202}$<smiles>CCOC(=O)C(=Nc1ccccc1)C(C)=O</smiles>

$16 \mathbf{a}$<smiles>N#CC(=Nc1ccccc1)C(=O)c1ccccc1</smiles>

16d

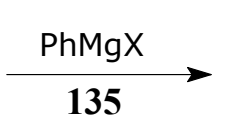<smiles>CCCCCCCCCCCCCC</smiles>

135

\section{Scheme 39}




\subsubsection{Reactions with nitrogen nucleophiles}

These reactions have been extensively investigated in the literature because of potential utility of formed arylazo heteroaromatics in dye industry. Quite a number of arylazopyrazolones and aminoarylazopyrazoles is commercialized. It is well established that $\mathbf{1 6 a}, \mathbf{b}, \mathbf{k}$ react with hydrazine derivatives 140 to yield pyrazolone 141 or arylazoaminopyrazoles 142 and $143 .{ }^{203-207}$<smiles>CCOC(=O)C(=N[GaH2])C(C)=O</smiles>

$16 \mathbf{a}$<smiles>CCOC(=O)/C(C#N)=N/[Mg]</smiles>

$16 b$<smiles>N#CC(C#N)=N[Br+]</smiles>

$16 \mathbf{k}$

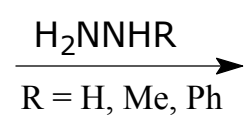

140

\section{$\mathrm{H}_{2} \mathrm{NNHR}$}

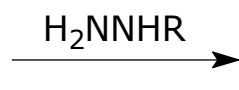

$\stackrel{\mathrm{H}_{2} \mathrm{NNHR}}{\longrightarrow}$<smiles>[R]N1N=C(C)C(=N)C1=O</smiles>

141
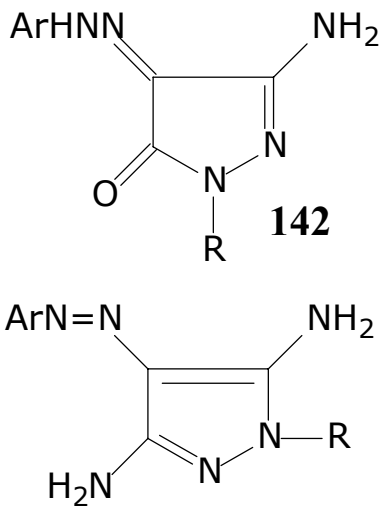

143

\section{Scheme 40}

Recently, however, Elnagdi et al. ${ }^{208}$ have reported that reaction of 144 with hydrazines affords the stable hydrazones $\mathbf{1 4 5}$. These could be cyclized only under drastic conditions into pyrazoles $\mathbf{1 4 6}^{\mathbf{2 0 9 - 2 1 1}}$. It can thus be suggested that this is beyond the stability of these hydrazones. Hydroxylamine hydrochloride reacts with 144 in basic media to yield isoxazolones $\mathbf{1 4 8 .}$. $^{212,213}$ However, again only oximes 147 were produced from reaction of 144 with hydroxylamine. The latter either cyclised into 1,2,3-triazoles $\mathbf{1 5 0}^{214,215}$ or were converted into nitriles $\mathbf{1 4 9}^{216}$ by action of acetic acid. Only upon reflux in $\mathrm{Ac}_{2} \mathrm{O}$ isoxazoles 148 were produced. 


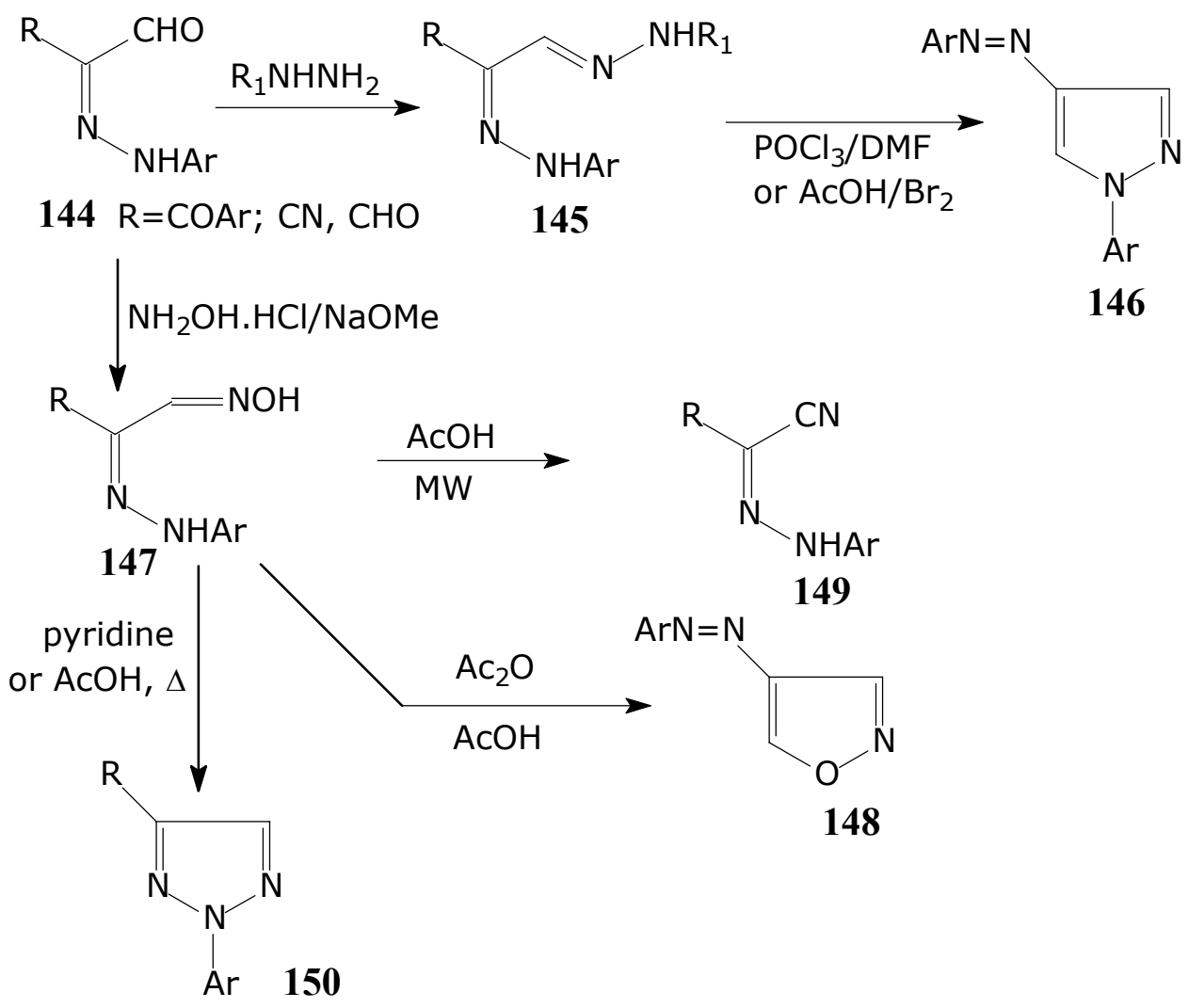

\section{Scheme 41}

The reaction of hydroxylamine hydrochloride with $\mathbf{1 6 b}, \mathbf{d}$ derivatives give amidoximes 151 that are converted into isoxazoles 152 upon reflux in ethanolic sodium ethoxide or treated with concentrated sulfuric acid. On the other hand when the reaction is conducted in ethanolic sodium ethoxide, isomeric 5-aminoisoxazoles 153 were produced. The dependence of the products on the applied reaction conditions is attributed to extra activation of cyano function in protic media. $^{217}$ 


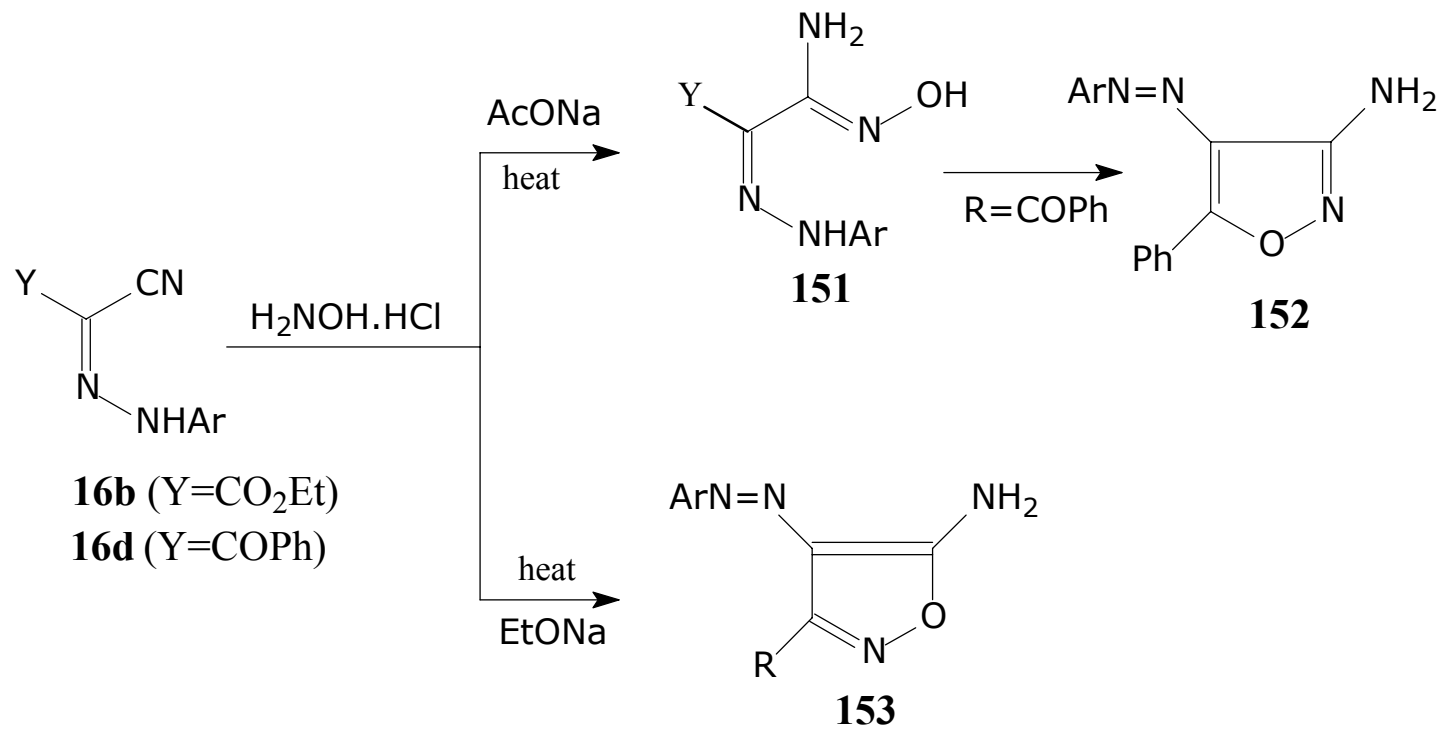

\section{Scheme 42}

The ester 144 afforded arylazopyrazoles 154 upon treatment with hydrazine hydrate in refluxing ethanol. ${ }^{218,219}$<smiles>CCOC(=O)/C(C=O)=N/NBr</smiles>

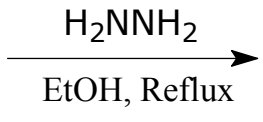

144: $\mathrm{R}=\mathrm{CO}_{2} \mathrm{Et}$<smiles>N/N=C1/C=NNC1=O</smiles>

154

\section{Scheme 43}

Aminopyrazoles 155 condense with arylhydrazonals to yield pyrazoles[1,2- $a$ ] pyrimidines 156-158 that rearranged in some cases when C-4 in pyrazole is unsubstituted into pyrazoles[3,4b]pyridines $\mathbf{1 5 9} .^{16,220}$ 

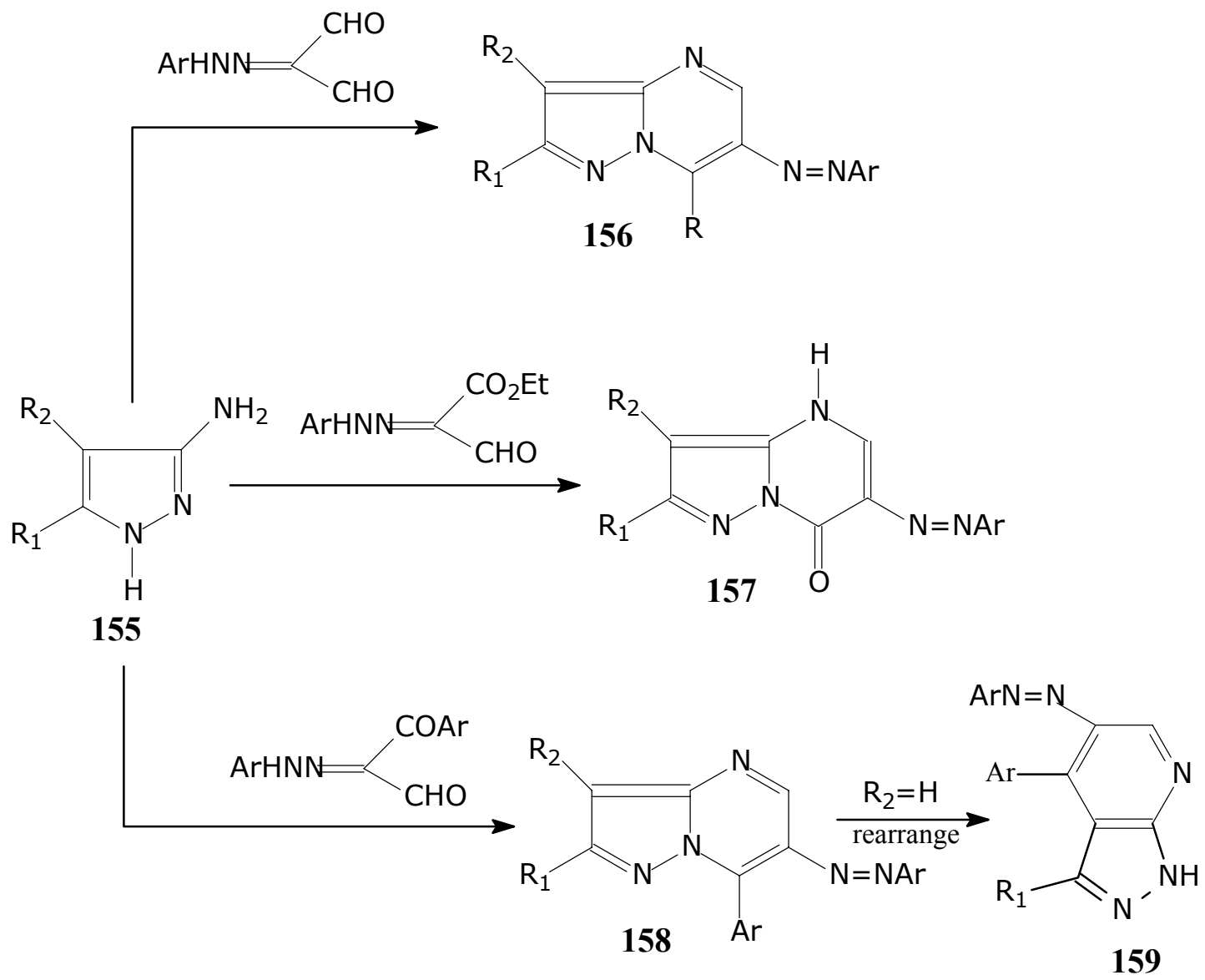

\section{Scheme 44}

In a similar way $1 H-1,2,4$-triazole-5-amine $\mathbf{1 6 0}$ reacted with arylhydrazonal to yield triazolo[1,5-a]pyrimidines 161. The structure of these derivatives was established by $\mathrm{x}$-ray diffraction analysis. ${ }^{198,221,222}$

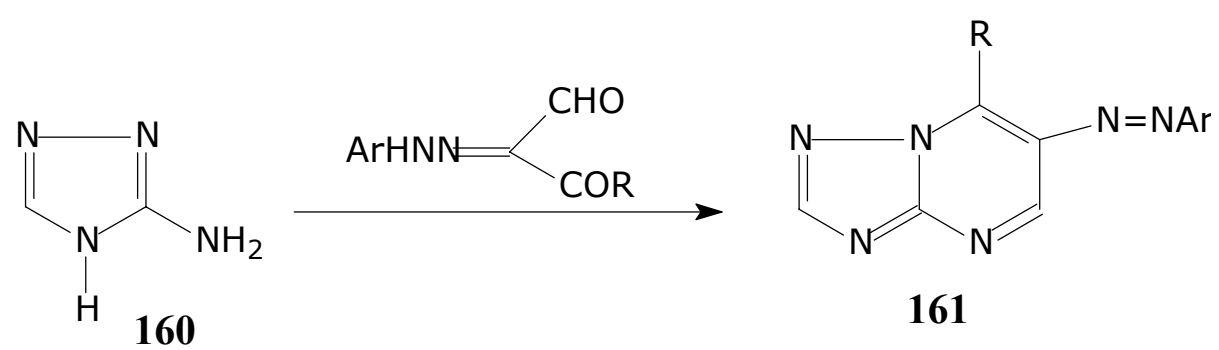

\section{Scheme 45}

2-Aminobenzothiazole reacts with $\mathbf{1 6 a}$ to yield $162 .^{223}$ 


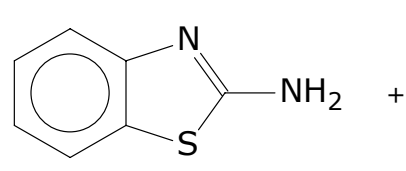<smiles></smiles>

162

\section{Scheme 46}

\subsubsection{Reaction with oxygen nucleophiles}

Hydrolysis of ester function in $\mathbf{1 6}$ and subsequent decarboxylation of the formed acid that readily decarboxylate into pyrovaldehyde-1-phenylhydrazone 163 by action of alcoholic or aquous sodium hydroxide is well established route to 163. The diester 164 is readily converted upon treatment with water into $16 .^{224,225}$ Again this old reaction should be rechecked as possible cyclization into pyridazin-4-one can not be overlooked.<smiles>CCOC(=O)/C(=N\NCl)C(C)=O</smiles>

16<smiles>CCOCC(=O)CC(=O)/C(=N/NCCO)C(=O)OCC</smiles><smiles></smiles><smiles>CCl</smiles>

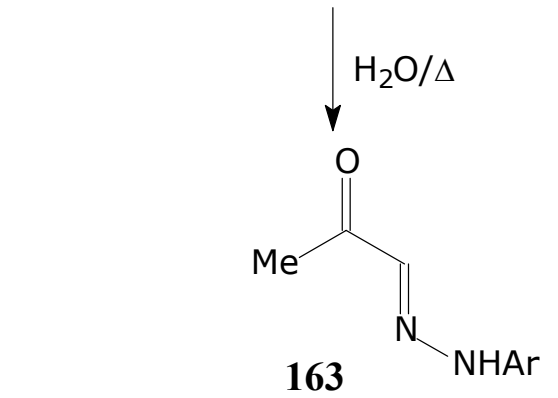

\section{Scheme 47}

3-Oxo-2-arylhydrazonals $144(\mathrm{R}=\mathrm{COMe})$ are reported to dimerise readily upon reflux in acid media. The structure of the dimer 165 was confirmed by X-ray crystal structure determination. ${ }^{170}$ 

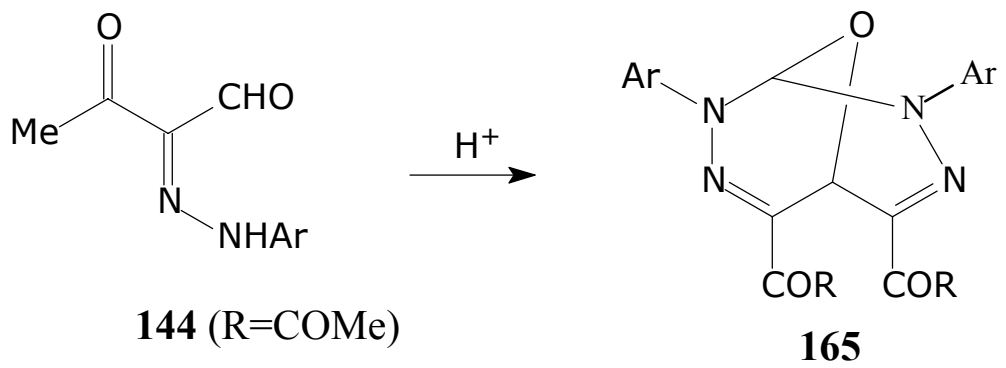

Scheme 48

\section{Intramolecular Processes}

2-Oxoarylhydrazones 16 are readily cyclised in presence of Lewis acids into 166. Similarly 144 are cyclised either by the action of polyphosphoric acid or upon pyrolysis in the gas phase into $167^{226,227}$<smiles>[R]C(=O)/C([X])=N\N</smiles>

16<smiles>[R]C(=O)/C(C=O)=N/N</smiles>

144
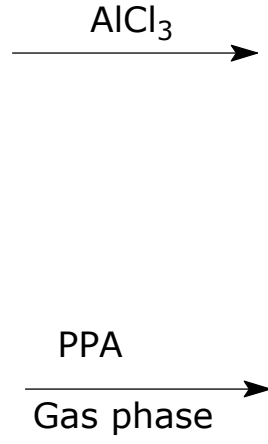<smiles>[X]c1nnc2ccccc2c1[R]</smiles>

166<smiles>[R]C(=O)c1cc2ccccc2nn1</smiles>

167

\section{Scheme 49}

Gas-phase pyrolysis of $\mathbf{1 6}$ gives $\mathbf{1 6 8}$ and $\mathbf{1 6 9}$ via a six-membered transition state. ${ }^{17,228}$

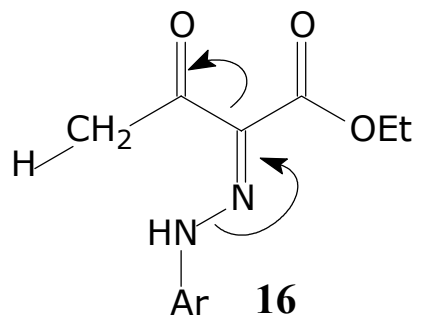<smiles>CCOC(=O)/C=N\N[Al-]</smiles>

183

Scheme 50 


\section{Reduction}

Reduction of arylhydrazone $\mathbf{1 6}$ at dropping mercury electrode proceeds in two successive 2e processes. Initially reductive cleavage of $\mathrm{N}-\mathrm{N}$ bond occurs. This is followed by $2 \mathrm{e}$ reduction of $\mathrm{C}=\mathrm{NH}$ yielding pi-functionally substituted amines. Again we believe that these results need to be rechecked as functional amines are unstable compounds and although may be formed in solution isolated products should be carefully identified by modern tools. ${ }^{229}$
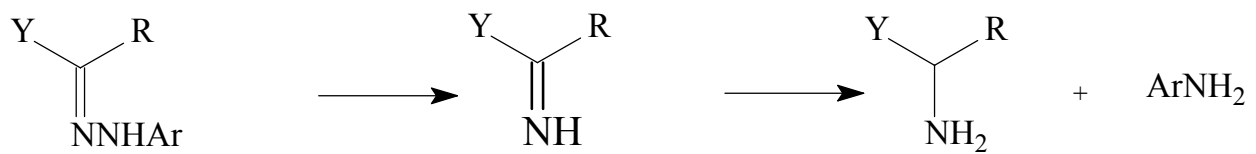

\section{Scheme 51}

The arylhydrazone moiety in $\mathbf{1 6}$ is reduced by sodium dithionate into aromatic amine and an $\alpha$-amino ester. While in potassium borohydride_(10\%) reduction of carbonyl group was occurred (cf. Scheme 52). ${ }^{230,231}$<smiles>CCOC(=O)/C(=N/N[Br+])Sc1ccc(S(=O)(=O)OCC)cc1</smiles><smiles>CCN/N=C(\C(=O)OCC)C(C)O</smiles>

$40 \%$

\section{Scheme 52}




\section{References}

1. Gordon, P. F.; Gregory, P. Organic Chemistry in Colour, Springer-Verlag: Berlin and New York, 1983; p 108.

2. Bradbury, R. Dyes for dye diffusion thermal transfer (D2T2) Printing, In A. T. Peters, H. S. Freeman, Eds., Advance in Colour Chemistry Series Vol. 3 Modern Colorants - Synthesis and Structure, Blackie, Academic: London, 1995.

3. Hunger, K. Ed. Industrial Dyes: Chemistry Properties, Applications, Wiley-VCH Verlag GmbH \& Co-KGaA: Weinheim, 2003.

4. Elnagdi, M. H. M. Sc. Thesis, Cairo University, 1966.

5. Severin,T.; Poehlmann, H. Chem.Ber. 1977, 110, 491.

6. Huisman, M.; Have, R.; van Leusen, A. M. Synth. Commun. 1997, 27, 945.

7. Alexakis, A.; Lensen, N.; Mangeney, P. Tetrahedron Lett. 1991, 32, 1171.

8. Katcka, M. Rocz. Chem. 1977, 51, 1455.

9. Reliquent, A.; Besbes, R.; Reliquent, F.; Meslin, J. C. Synthesis 1991, 7, 543.

10. Lerche, H.; Fischer, H.; Severin, T. Chem. Ber. 1985, 118, 3011.

11. Nelsen, S. F.; Willi, M. R. J. Org. Chem. 1986, 51, 2081.

12. Beyer, C.; Claisen, L. Chem. Ber. 1888, 21, 1697.

13. Buelow, C.; Schlotterbeck, V. F. Chem. Ber. 1902, 35, 2187.

14. Auwers, K. von J. Liebigs Ann. Chem. 1911, 379 , 229.

15. Elguero, J.; Jacquier, R.; Tarrago, G. Bull. Soc.Chim. Fr. 1966, 2990.

16. Elgemeie, G. E. H.; El-Zanate, A. M.; Mansour, A. K. E. Bull. Chem. Soc. Jpn. 1993, 66, 555.

17. AL- Awadi, N. A.; El-Nagdi, M. H.; Mathew, T. Chem. Kinet. 1995, 27, 517.

18. Jain, R.; Agarwal, D. D.; Shrivastava, R. K. J. Indian Chem. Soc. 1990 , 67, 204.

19. Potapov, V. M.; Panova, G. V.; Turovets, I. M. J. Gen. Chem. USSR. 1984, 54, 1061; Zh. Obshch. Khim. 1984, 54, 1185.

20. Elgemeie, G. H.; EL-Ezbawy, S. R.; Ramiz, M. M.; Mansour, O. A. Org. Prep. Proced. Int. 1991, 23, 645.

21. Drew, M. G. B.; Vickery, B; Willey, G. R. J. Chem. Soc., Perkin Trans. 2 1982, 1297.

22. Lifschitz, J. Chem. Ber. 1914, 47, 1401.

23. Leuckart,V.; Holtzapfel, H. V. Chem. Ber. 1889, $22,1408$.

24. Buelow, C. Chem. Ber. 1899, 32, 208.

25. Patel, H. V.; Fernandes, P. S.; Vyas, K. A. Indian J. Chem. Sect. B. 1990, 29, 1044.

26. Buelow, C.; Engler, R. Chem. Ber. 1918, 51, 1264.

27. Sadanadam, Y. S.; Shetty, M. M.; Margaret, I.; Diwan, P. V. Eur. J. Med. Chem. Chim. Ther. 1991, 26, 567.

28. Andrisano; P. Ann. Chim. (Rome) 1950, 40, 292.

29. Knorr, L.; Reuter, B. Chem. Ber. 1894, 27, 1170. 
30. Lisitsyna, E . S .; Tambieva, O.A.; Ezhkova, Z. I.; Zaitseva, B. E.; Petrova, K.R.; Dyumaev, K. M. Chem. USSR (EN) 1983, 56, 2, 339; Zh.Prikl. Khim. (Leningrad) Ru. 1983, 56, 358.

31. Jain, R.; Dixit, A.; Pandey, P. J. Indian Chem. Soc. 1989, 66, 486.

32. Yagi, Y.; Bull. Chem. Soc. Jpn. 1963, 36, 407.

33. Agarwal, D. D.; Agarwal, V. J. Indian Chem. Soc. 1991, 68, 360.

34. Jain, R.; Pandey, P.; Jain, S. J. Indian Chem. Soc. 1990, 67, 350.

35. Kumar, A.; Sharma, P.; Sharma, R. Indian J. Chem. Sect. 2003, 42B, 363 .

36. Kalluraya, B.; Rahiman, A. M.; Banji, D. Arch. Pharm. 2001, 334, 263.

37. Sharma, P.; Pritmani, S. Indian J. Chem. Sect. 1999, 38B, 1139.

38. Ramana, P. V.; Ravindranath, L. K. J. Indian Chem. Soc. 1999, 76, 112.

39. Amir, M.; Agarwal, R. J. Indian Chem. Soc. 1997, 74, 154.

40. Turel, R. J.; Manerikar, S. V.; Kulkarni, A. B. Indian J. Chem. Sect. 1980, 19B, 676.

41. Garg, G.; Singh, P. P. J. Med. Chem. 1968, 11, 1104.

42. Sparatore, F.; Pagani, R. Ann. Chim (Rome) 1962, 52, 248.

43. Karrer, P.; Hershberg, E. B. Helv. Chim. Acta. 1943, 17, 1019.

44. Meyer, K. H.; Lenhardt, S. J. Liebigs Ann. Chem. 1913, 398, 69.

45. Buelow, C; Hoepfner, W. Chem. Ber. 1901, 34, 81.

46. Wedekind, E. Chem. Ber. 1899, 32, 1919.

47. Buelow, C. Chem. Ber. 1898, 31, 3123.

48. Kjellin, C. Chem. Ber. 1897, 30, 1968.

49. Richter V. V.; Muenzer, H. Chem. Ber. 1884, 17, 1926.

50. Bamberger, E. Chem. Ber. 1884, 17, 2421.

51. Haller, A. C. R. Hebd. Seances Acad. Sci. 1888, 106, 1171.

52. Krueckeberg, F. J. Prakt. Chem. 1894, 49, 323.

53. Haller, A.; Brancovici, E. C. R. Hebd. Seances Acad. Sci. 1893, 116, 715.

54. Uhlmann, P. W. J. Prakt. Chem. 1895, 51, 218.

55. Meyer, E.V.; Marquardi, B. J. Prakt. Chem. 1895, 52, 167.

56. Favrel, G. Bull. Soc. Chim. Fr. 1902, 27, 201.

57. Lax, W. J. Prakt. Chem. 1901, 63, 11.

58. Weissbach, H. J. Prakt. Chem. 1903, 67, 402.

59. Panizzi, L. Gazz. Chim. Ital. 1947, 77, 206.

60. Leonnard, N.J.; Boyd, S.N.; Herbrandson, H. F. J. Org. Chem. 1947, 12, 47.

61. Barber, H. J.; Washboren, K.; Wragg, R.; Lunt, E. J. Chem. Soc. 1961, 2828.

62. Brecknell, D. J.; Carman, R. H.; Deeth, H. C.; Kibby, J. J. Aust. J. Chem. 1969, 22, 1915.

63. Khalifa, M. A. E.; Tammam, G. H.; Abdel-Motaleb, R. M.; Elnagdi, M. H. Heterocycles, 1983, 20, 45.

64. Prasad, D.; Prasad, N.; Prasad, R. M.; Ferrier, R. J.; Milgate, S. M. J. Chem. Soc., Perkin Trans. 1 1984, 7, 1397.

65. Shawali, A., S.; Albar, H. A. Can. J. Chem. 1986, 64, 871.

66. Abou-Elenien, G. M.; Ismail, N. A.; Hafez, T. S. Bull. Chem. Soc. Jpn. 1991, 64, 651. 
67. Haller, A. C. R. Hebd. Seances Acad. Sci. 1889, 108, 1117.

68. Shawali, A. S.; Osman, A. Tetrahedron. 1971, 27, 2517.

69. Shawali, A.S.; Abd EL-Galil, M. Tetrhedron 1971, 27, 4305.

70. Meyer,V. E. J. Prakt. Chem. 1895, 52, 110.

71. Gewald, K.; Hain, U. J. Prakt. Chem. 1975, 317, 329.

72. Du Pont de Nemours; US3179651, 1963; Chem.Abstr. 1965, 63, 1734d.

73. Weissbach, H. J. Prakt. Chem. 1898, 57, 207.

74. Katritzky, A. R.; Belyakov, S. A.; Cheng, D.; Durst, H.D. Synthesis 1995, 577.

75. Perkin, W. H. Chem. Ber. 1883, 16, 340.

76. Bazavova, I. M.; Dubenko, R. G.; Neplyuev, V. M.; Pel'kis, P. S. Zh. Org. Khim. 1974, 10, 308.

77. Beu, R. Rev. Roum. Chim. 1974, 19, 1825.

78. Elgemeie, G. E. H.; Aal, F. A. A. Heterocycles. 1986, 24, 349 .

79. Elneairy, M. A. A.; Abdel-Rahman, T. M.; Hammad, A. M. J. Chem. Res. 1998, 11, 2834.

80. Rudnev, M. I.; Kurbatov, V. P.; Chub, N. K.; Osipov, O. A. J. Gen. Chem. 1988, 58, 2077. Obshch. Khim. 1988, 58, 2334.

81. Cankar, P.; Slouka, J. J. Heterocycl. Chem. 2003, 40, 71 .

82. Shams, H. Z.; Khalifa, F. A.; Barsoum, B. N.; Naoum, M. M. Bull. Soc. Chim. Fr. 1989, 1, 119 .

83. Elmoghayar, M. R. H.; Abdalla, S. O.; Nasr, M. Y. J. Heterocycl. Chem. 1984, 21, 781.

84. Elmoghayar, M. R. H.; Ghali, E. A.; Ramiz, M. M. M.; Elnagdi, M. H. Liebigs Ann. Chem. 1985, 10, 1962 .

85. Fahmy, H. M.; Azzem, A. M.; Wahab, A. M.; Fattah, A. N.; Aboutabl, M. A. Bull. Chem. Soc. Jpn. 1989, 62, 2650.

86. Al-Motary, M. H.; Riad, S.; Elnagdi, M. H. Org. Prep. Proceed Int. 2007 (In Press).

87. Ibrahim, N. S.; Galil, F. A.; Abdel-Motaleb, R. M.; Elnagdi, M. H. Heterocycles 1986, 24, 1219.

88. Begtrup, M.; Holm. J. Chem. Soc., Perkin Trans 1 1981, 503.

89. Potapov, V. M.; Panova, G. V.; Turovets, I. M.; Kasumov, R. D.; Vikulova, N. K. Chem. USSR. 1983, 53, 1214; Obshch. Khim. 1983, 53, 1353.

90. Upjohn Co.; DE 2157601, 1971; Chem. Abstr. 1971, 77, 88470.

91. Michael, A. Chem. Ber. 1905, 38, 2083.

92. Claisen, L. Chem. Ber. 1903, 36, 3671.

93. Pechmann, H. C.; Wehsarg, G. Chem. Ber. 1888, 21, 3003.

94. Shvedov, V. I. Chem. Heterocycl. Compd. 1975, 11, 1059; Khim. Geterotsikl. Soedin. 1975, $11,1217$.

95. Elassar, A. A. J. Chin. Chem. SOC. 2006, 53, 901.

96. Benary, E. Chem. Ber. 1927, 60, 914.

97. Al-Mousawi, S.; Abdel-Khalik, M. M.; El-Sherbiny, S.; John, E.; Elnagdi, M. H. J. Heterocycl. Chem. 2001, 38, 949. 
98. Al-Shiekh, M. A.; EL-Din, A. M. S.; Hafez, E. A.; Elnagdi, M. H. J. Chem. Res. 2004 , 174

99. Al-Shiekh, M. A.; El-Din, A. M.; Hafez, E. A.; Elnagdi, M. H. J. Heterocycl. Chem. 2004, 41,647 .

100.Severin,T.; Poehlmann, H. Chem. Ber. 1978, 111, 1564 .

101.Abdel-Khalik, M. M.; Elnagdi, M. H.; Agamy, S. M.; Synthesis 2000, 8, 1166.

102.Al-Saleh, B.; El- Apasery, M. A.; Elnagdi, M. H. J. Heterocycl. Chem. 2005, 42, 483.

103. Al-Naggar, A. A.; Abdel-Khalik, M. M.; Elnagdi, M. H. J. Chem. Res. 1999, 11, 2801 .

104.Al-Omran, F.; Al- Awadi, N.; Yousef, O.; Elnagdi, M. H. J. Heterocycl. Chem. 2000, 37, 167.

105.Dib, H. H.; Al-Awadi, N. A.; Ibrahim, Y. A.; El-Dousoqi, O. M. E. Tetrahedron 2003, 59, 9455 .

106. Abdel-Megid, M.; Elnagdi, M. H.; Negm, A. M. J. Heterocycl. Chem. 2002, 39, 105.

107. Mohamed, M. H.; Abdel-Khalik, M. M.; Elnagdi, M. H. J. Heterocycl. Chem. 2001, 38, 685.

108. Hassanien, A. Z. A.; Ghozlan, S. A. S.; Elnagdi, M. H. J. Chin. Chem. Soc. 2004, 51, 575.

109.Japp, F. R.; Klingemann, F. Justus Liebigs Ann. Chem. 1888, 247, 209.

110.Favrel, G. C. R. Hebd. Seances Acad. Sci. 1901, 132, 1336; Bull. Soc. Chim.(Fr.) 1902, 27, 336.

111.Linstead, R. P.; Wang, A. B.-L. J. Chem. Soc. 1937, 807.

112.Brecknell, D. J.; Carman, R. M.; Deeth, H. C.; Kibby, J. J. Aust. J. Chem. 1969, 22, 1915.

113.Kalb, L.; Schweizer, F.; Schimpf. G. Chem. Ber. 1926, 59, 1859.

114. Bamberger, E.; de Gruyter, P. J. Prakt. Chem. 1901, 64, 239.

115. Bertini, R. Gazz. Chim. Ital. 1901, 311, 579.

116. Crundmann, C.; Fulton, M. B. Chem. Ber.1964, 97, 566 .

117.Irving, J. Chem. Soc. 1936, 797, 801.

118.Bonnema, J.; Arens, J. F. Recl. Trav. Chim. Pays-Bas. 1960, 79, 1137.

119.Bamberger, E.; de Gruyter, P. J. Prakt. Chem. 1901, 64, 239.

120.Simon, L. J. C. R. Hebd. Seances Acad. Sci. 1900, 131, 684.

121.Japp, F. R; Klingemann, F. Chem. Ber. 1887, 20, 2942.

122.Fischer, E.; Jourdan, F. Chem.Ber. 1883, 16, 2241.

123.Feofilaktow, V. V.; lvanov, T. N. Zh. Obshch. Khim. 1943, 13, 457; Chem. Abstr. 1944, 3255.

124.Feofilaktow, V. V. Izv. Akad. Nauk SSSR Ser. Khim. 1941, 521, 529; Chem. Abstr. 1943, 2347.

125. Wislicenus, W.; Waldmueller, M. Chem. Ber. 1911, 44, 1571.

126.Sakutskaja, V. Zh. Obshch. Khim. 1940, 10, 1557; Chem. Zentralbl. 1941, 112, 2657.

127.Linstead, R. P.; Wang, A. J. Chem. Soc. 1937, 807, 813.

128. Blaise, E. E.; Gault, H. Bull. Soc. Chim. Fr. 1911, 9, 463.

129. Carter, C. L. J. Soc. Chem. Ind. (London) 1943, 62, 238.

130. Reimann, E.; Erdle, W.; Unger, H. Pharmazie. 1999, 54, 418. 
131.Fischer, E. Ach Justus Liebigs Ann. Chem. 1889, 253, 64.

132. Shou, X.; Miledi, R.; Chamberlin, A. R. Bioorg. Med. Chem. Lett. 2005, 15, 3942.

133. Grundmann, C.; Fulton, M. B. Chem. Ber. 1964, 97, 566.

134.Ancel, J. E.; Kaim, L. E.; Gadras, A.; Grimaud, L.; Jana, N. K.; Tetrahedron Lett. 2002, 43, 8319.

135. Simunek, P.; Peskova, M.; Bertolasi, V.; Lycka, A.; Machacek, V. Eur. J. Org. Chem. 2004, 24, 5055.

136.Simunek, P.; Peskova, M.; Bertolasi, V.; Machacek, V.; Lycka, A. Tetrahedron 2005, 61, 8130.

137. Bamberger, E.; Schmidt, O. Ber. Dt. Chem. Ges. 1901, 34, 2001.

138. Shapiro, D.; Abramovitch, R. A.; Pinchas, S. J. Am. Chem. Soc. 1956, 78, 2144.

139. Abramovitch, R. A.; Spenser, I. D. J. Chem. Soc. 1957, 3767.

140.Bannore, S. N.; Wadia, M. S.; Bose, J. L. Ind. J. Chem. 1970, 8, 410.

141. Tanner, E. M. Spectrochim. Acta 1959, 15, 20.

142. Yoder, C. H.; Kemmedy, S.; Snavely, F. A. J. Org. Chem. 1978, 43, 1077.

143.El Khadem, H. S.; Kreishman, G. P.; El Ashry, E. H. J. Org. Chem. 1975, 40 (21), 3149.

144.(a) Al-Shiekh, M. A.; EL-Din, A. M. S.; Hafez, E. A., Elnagdi, M. H. J. Heterocycl. Chem. 2004, 41, 647. (b) Ghozlan, S. A. S.; Abdelhamid, I. A.; Elnagdi, M. H. ARKIVOC 2006, (xiii), 147. (c) Aziz, S. I.; Anwar, H. F.; Fleita, D. H.; Elnagdi, M. H. J. Heterocyl. Chem. 2007, 44, 725 .

145.El-Dusouqui, O. M. E.; Abdelkhalik, M. M.; Al-Awadi , N. A.; Dib, H. H.; George, B. J.; Elnagdi, M. H. J. Chem. Res. 2006, 291.

146.Hafez, E. A.; Elnagdi, M. H; Al-Zaydi, K. M. Unpublished data.

147. Mustafa, A.; Asker, W.; Harhash, A.; Nessina, N.; Elnagdi, M. H. Tetrahedron 1965, 21, 217.

148.Hahn, W. Soc. Sci. Lodz. Acta Chim. 1959, 4, 117.

149.Ried, W; Keil, G. Justus Liebigs Ann. Chem. 1957, 605, 167.

150.Hahn, W. Soc. Sci. Lodz. Acta Chim. 1960, 4, 101; Chem. Abstr. 1961, 5525.

151.Harhash, A. H.; Mansour, A. K.; Elnagdi, M. H.; Elmaghayer, M. R. H. J. Prakt. Chem. 1973, 315, 235.

152.Hassaneen, H. M. E.; Abdallah, T. A.; Hassaneen, H. M.; Elnagdi, M. H. J. Chem. Res. 2005, 11, 729 .

153. Michaelis. A. Justus Liebigs Ann Chem. 1906, 350, 318.

154.Panzzi, L.; Monti, E. Gazz. Chim. Ltal. 1947, 77, 556.

155.Ghouzlan, S. A. S.; Abdelhamid, I. A.; Hassaneen, H. M.; Elnagdi, M. H. J. Heterocyl. Chem. 2006, 43, 1.

156.Patel, H. V.; Fernandes, P. S. Indian J. Chem. Sect. B 1988, 27, 1154.

157.Kandeel, E. M.; Sadek, K. U.; Elnagdi, M. H. Z. Naturforsch. B Anorg. Chem. Org. Chem. 1980, 35, 91.

158. Favrel, G. Bull. Soc. Chim. Fr. 1930, 47, 1290. 
159.Gewald, K.; Rehwald, M.; Mueller, H.; Bellmann, P.; Schaefer, H. Monatsh. Chem. 1995, 126, 341.

160.Salah, A. M.; Abdallah, T. A.; Radwan, N. F.; Hassaneen, H. M. Z. Naturforsch, 2006, 61b, 1.

161.Russell, P. B. J. Am. Chem. Soc. 1953, 75, 5315.

162. Castellana, V. Gazz. Chim. Ital. 1906, 36, 11.

163. Buelow, C; Hailer, E. Chem. Ber. 1902, 35, 928.

164. Sharp, B. J. Am. Chem. Soc. 1949, 71, 1106.

165.(a) Abdellah, S. O.; Metwally; N. H.; Anwar, H. F. Elnagdi, M. H. J. Heterocycl. Chem. 2005, 47, 781. (b) Hassan, Z. M. A.; M. Sc., Cairo University, 1999.

166. Patel, H. V.; Fernandes, P. S. Indian J. Chem. Sect. B; 1988, 27, 1154.

167. Attanasi, O. A.; Filippone, P.; Fiorucci, C.; Mantellini, F.; Tetrahedron Lett. 1999, 40, 3891.

168.Patel, H. V.; Fernandes, P. S; Vyas, K. A. Indian J. Chem. Sect. B. 1990, 29, 1044.

169.Daniel, J.; Dhar, D. N. Heterocycles. 1991, 32, 8,

170. Bamberger, E.; Wheelwright, E. W. J. Prakt. Chem.1902, 65, 123.

171. Ghozlan, S. A. S.; Abdelhamid, I. A.; Gaber, H. M.; Elnagdi, M. H. J. Heterocycl. Chem. 2005, 42, 1185.

172. AL-Zaydi, K. M.; Elnagdi, M. H. Z. Naturforsch. Sec. B-A. J. Chem. Sci. 2004, 59, 721.

173. Chattaway, F. D.; Ashworth, D. R. J. Chem. Soc. 1933, 1143.

174. Bowack, D. A.; Lapworth, A. J. Chem. Soc. 1905, 87, 1859.

175. Chattaway, F. D; Lye. Proc. R. Soc. London A 1932, 137, 489.

176. Chattaway, F. D.; Ashworth, D. R. J. Chem. Soc. 1933, 478; J. Chem. Soc. 1934, 430.

177. Sharp, B.; Hamilton, C. S. J. Am. Chem. Soc. 1946, 68, 588.

178. Tewari, R. S.; Parihar, P. Tetrahedron 1983, 39, 129.

179. Fusco, R.; Rossi, S. Gazz. Chim. Ital. 1956, 86, 484.

180. Chattaway, F. D.; Ashworth, D. R. J. Chem. Soc. 1933, 1143.

181. Chattaway, F. D.; Ashworth, D. R. J. Chem. Soc. 1934, 1985.

182. Buelow, C.; Seidel, F. Chem. Ber. 1924, 57, 630.

183. Moon, M. W. J. Org. Chem. 1972, 37, 386.

184. Elnagdi, M. H.; Erian, A. W.; Sadek, U.; Selim, M. A. J. Chem. Res. 1990, 5, 1124.

185. Elnagdi, M. H.; Abdelrazek, F. M.; Ibrahim, N. S.; Erian, A. W. Tetrahedron 1989, 45, 3597.

186. Elnagdi, M. H.; Maksoud, F. A.; Aal, A.; Hafez, E. A. A.; Yassin, Y.M. Z. Naturforsch. B 1989, 44, 683.

187. Sotelo, E.; Mocelo, R.; Suarez, M.; Loupy, A. Synth.Commun. 1997, 27, 2419.

188. El-Kousy, S.; El-Sakka, I.; El-Torgoman, A. M.; Roshdy, H.; Elnagdi, M. H. Collect. Czech. Chem. Commun. 1990, 55, 2977.

189. Fathy, N. M.; Motti, F. M. A.; Elgemeie,G.E.H. Arch. Pharm. 1988, 321, 509.

190. El-Bannany, A. A.; Elassar, A. A.; El-Nagdy, M. H. J. Prakt. Chem. 1989, 331, 726. 
191. Al-Mousawi, S.; Elassar, A.; El- Apasery, M. A. Phosph., Sulfur and Silicon and the Related Elements 2006, 181, 1755.

192. Barsy, M. J. Chin. Chem. Soc. 2000, 47, 951.

193. El- Kousy, S. M.; Mohareb, R. M.; Riad, M.; Elnagdi, M. H. Pak. J. Sci. Ind. Res. 1998, 41, 81.

194. Elnagdi, M. H.; Barsy, M. A. A.; Abdel- Latif, F. M.; Sadek, K.U. J. Chem. Res. 1998, 1, 188.

195. Nada, A. A.; Erian, A.W.; Mohamed, N. R.; Mahran, A. M. J. Chem. Res. 1997, 7, 1576.

196. Patel, H., V.; Vyas, K., A.; Pandey, S. P.; Tavares, F.; Fernandes, P. S. Synth. Commun 1991, 21,1021.

197. Abdel-Khalik., M. M.; Agamy, S. M.; Elnagdi, M. H. Synthesis 2001, 1861.

198. Al-Shiekh, M. A.; El-Din, A. M. S.; Hafez, E. A.; Elnagdi, M. H. J. Heterocycl. Chem. 2004, 41, 647.

199. Bestmann, H. J.; Schmid, G.; Sandmeier, D.; Schade, G.; Oechsner, H. Chem. Ber. 1985, $118,1709$.

200. Prager, B. Chem. Ber. 1903, 36, 1453.

201. Patel, H. V.; Fernandes, P. S. Indian J. Chem. Sect. B. 1989, $28,733$.

202.Abdel-Motaleb, R. M.; Makhloof, A. -M. A.; Ibrahim, H. M.; Elnagdi, M. H. J. Heterocycl. Chem. 2006, 43, 931.

203. Taylor, E. C. Jr.; Barton, J. W.; Osdene, T. S. J. Am. Chem. Soc. 1958, 80, 421.

204. Wrubel, J.; Mayer, R. Z. Chem. 1984, 24, 256.

205. Shawali, A. S.; Abdelkader, M. H.; Attalbawy, F. M. Tetrahedron 2002, 58, 2875.

206. Elnagdi, M. H.; Abdoula, S.O. J. Prakt. Chem. 1973, 315, 1009.

207. Elnagdi, M. H.; Fleita, D. H.; Elmoghayer, M. R. H. Tetrahedron 1975, 31, 63.

208. Al-Saleh, B.; El-Apasery, M. A.; Abdel-Aziz; Elnagdi, M. H. J. Heterocycl. Chem. 2005, 42, 563.

209. Pechmann, H. O.; Vanino, L. Chem. Ber. 1894, 27, 222.

210. Zincke, T.; Kegel, O. Chem. Ber. 1889, 22, 1479.

211. Levy, S.; Witte, F. C. Justus Liebigs Ann. Chem. 1889, 252, 345.

212. Meyer, V. J. Prakt. Chem. 1895, 52, 89.

213. Buelow, C.; Busse, F. Chem. Ber. 1906, 39, 2459.

214.Riebsomer, J. L.; Stauffer D. A. J. Org. Chem. 1951, 16, 1643.

215.Jonas, A.; Pechmann, H. V. Justus Liebigs Ann. Chem. 1891, 262, 277.

216. Abdel-Khalik, M. M.; Agamy, S. M.; Elnagdi, M. H. Z. Naturforsch. B. 2000, 55, 1211.

217.Elnagdi, M. H. J. Org. Chem. 1975, 40, 2604.

218. Mahmoud, M. R.; Adam, F. A.; Yousef, K.; El-Haty, M. T . Bull. Soc. Chim. Belg. 1983, 92, 13.

219. Abd-Allah, E. M.; Rageh, N.M.; Salman, H. M. A. J. Chem. Eng. Data. 2003, 48, 652.

220.Ghozlan, S. A. S.; Abdelhamid, I.A.; Gaber, H.; Elnagdi, M. H. J. Chem. Res. 2004, 12, 789. 
221. Metwally, M. A.; Yousif, M. Y.; Ismaiel, A. K. M.; Etman, H. A. Heterocycles. 1985, 23, 2251.

222. Shionogi U. Co Ltd; Jp 6281; 1958; Chem. Abstr. 1964, 60, 9389.

223.El- Sherbeny, M. A. Arzneim. Forsch. 2000, 50, 848.

224. Claisen, L.; Roosen, P. Justus Liebigs Ann. Chem. 1894, 278, 295.

225.Bischler, A.; Oser, W. Chem. Ber. 1893, 26, 1881.

226.Kumar, A.; Al-Awadi, N. A.; Elnagdi, M. H.; Ibrahim, Y.A.; Kaul, K. Int. J. Chem. Kinet. 2001, 33, 402 .

227.Al-Awadi, N. A.; Elnagdi, M.H.; Ibrahim, Y. A.; Kaul, K.; Kumar, A. Tetrahedron 2001, 57, 1609.

228.Al-Awadi, N. A.; Elnagdi, M. H.; Al-Awadhi, H., A.; El-Dousouqi, O. M. E. Int. J. Chem. Kinet. 1998, 30, 457.

229.Elnagdi, M. H.; Fahmy, H. M.; Morsi, M. A. J. Electroanal. Chem. 1976, 68, 237.

230. Bowman, E.; Franklin, C. S. J. Chem. Soc. 1957, 1583.

231. Malik, W. U.; Jain, R. J. Indian Chem. Soc. 1982, 59, 191.

\section{Authors}

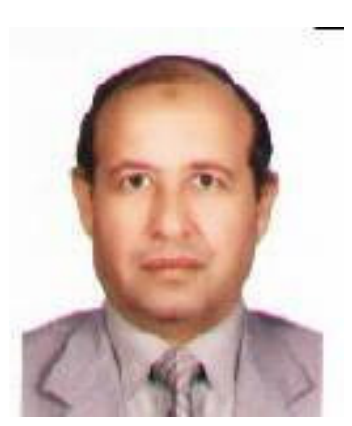

Abdel-Zaher A. Elassar was born in 1960 in Monoufia, Egypt. He received his BSc in chemistry (First class Honors with Distinction from Monoufia University, Egypt, in 1982. Both MSc (Organic Synthesis) and PhD (Organic Polymer Chemistry) were received from Helwan University, Cairo, Egypt, 1988 and 1993, respectively. He was promoted to the rank of associated professor in 2000. He worked at the National Center of Radiation Research and Technology, Cairo, Egypt (1983) and moved in the same year to the Chemistry Department, Helwan University, Cairo, Egypt, where he stayed until 1993. He joined the Chemistry Department, Kuwait University in 1993. His biographical profile was selected for inclusion in the $6^{\text {th }}$ Edition of Who's Who in Science and Engineering, USA. His research interests include organic synthesis, with emphasis on the design and synthesis of new ring system of azoles and azines and the study of their biological activity; organic polymers, concentrated on the modification of the polymeric material for novel synthesis, and use of polymers for waste treatment via metal-complexation. 


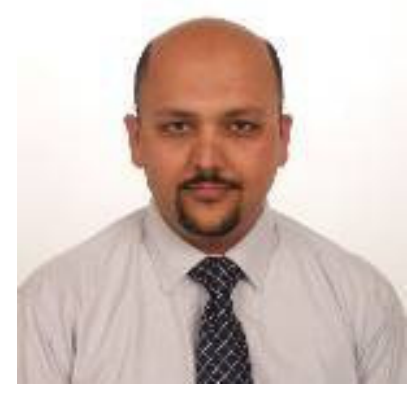

Hicham H. Dib was born in Lebanon in 1972, and obtained BSc. in Chemistry in 1995 from the Faculty of Science at Beirut Arab University, Beirut, Lebanon, and BS.c of Information (AudioVisual) in 2001 from the Lebanese University, Lebanon. He obtained MSc. in Chemistry in 2002 from the Faculty of Science at University of Kuwait, Kuwait. Currently, he is a Ph.D candidate and Teaching Assistant at Kuwait University. He was awarded Faiza Al-Khrafi Prize of Scientific Distinction for Graduate Students in June, 2004. He has more than 15 publications.

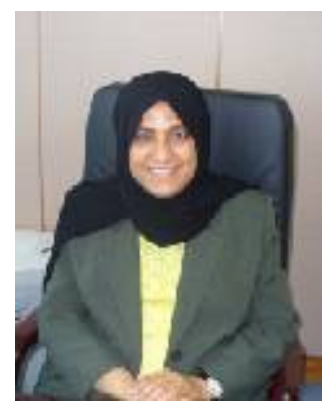

Nouria Al-Awadi was born in Kuwait and obtained her B.Sc. from the Faculty of Science at Kuwait University in 1976 and Ph.D. from the University of Kent, UK, in 1979. She held a postdoctoral fellowship at the University of Sussex (1981-82). Prof. Al-Awadi is FRCS and chartered scientist of RSC. She has been professor of organic chemistry at the University of Kuwait since 1992. Prof. Al-Awadi has held several administrative positions at Kuwait University: Vice dean of the College of Graduate Studies at Kuwait University (1984-90); Head of the Chemistry Department (1992-95); dean of Faculty of Science (1995-2001); Prof. AlAwadi since September 2006 until now is vice-president of Kuwait University for academic affairs. Prof. Al-Awadi has specialized in studying kinetics and mechanisms of gas-phase reactions and their potential utility as green methodologies in organic chemistry. She has more than 95 published papers and one patent. She is author of three review articles. 


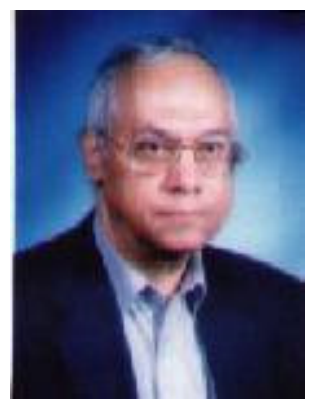

Mohamed Hilmy Elnagdi was born in Egypt in September 1941. He graduated from the Faculty of Science at Cairo University in 1962; since that date, Prof. Elnagdi has worked at Cairo University, Faculty of Science, in the Chemistry Department. Prof. Elnagdi obtained his M.Sc. in 1966, Ph.D. in 1969, and D.Sc. in 1982. He has also been awarded a Diploma in Applied Chemistry from Tokyo Institute of Technology in 1973. Prof. Elnagdi has been professor of organic chemistry at Cairo University since 1980. He worked as professor of organic chemistry at Kuwait University from 1993 to 1999, then as visiting professor at the same university in 2003.

Since March 2007 Prof. Elnagdi has shifted back to the University of Kuwait with intention to end his career there. Prof. Elnagdi has received fellowships from several institutions, including those from the Royal Norwegian Council for Scientific and Industrial Research, taken at University of Oslon (1977); Visiting Associate Professor at the University of Utah in 1976 with Prof. L. B. Townsend; Alexander von Humboldt Fellowship at University of Bonn with Profs. H. Wamhoff and R. Regitz. The Alexander von Humbolt Foundation has continually supported his activities in Germany, enabling him to cooperate with many German colleagues including Profs. K. Hafner, K. S. Hartki, M. Hoffmann, and H. H. Otto. Prof. Elnagdi has specialized in the synthesis of polyfunctional heterocycles and has published around 300 papers in this area as well as 15 review articles. In addition, Prof. Elnagdi is cooperating with the Al-Awadi group at Kuwait University, where he is co-author on 30 papers. He has received several national and regional awards for his research output, including the TWAS Chemistry and COMESTECH awards. 